\title{
A blue-ice ecosystem on the margins of the East Antarctic ice sheet
}

\section{Andy HODSON, ${ }^{1,2}$ Harriet PATERSON, ${ }^{3}$ Karen WESTWOOD, ${ }^{4}$ Karen CAMERON, ${ }^{5}$ Johanna LAYBOURN-PARRY ${ }^{6}$}

\author{
${ }^{1}$ Department of Geography, University of Sheffield, Sheffield, UK \\ E-mail: a.j.hodson@sheffield.ac.uk \\ ${ }^{2}$ Arctic Geology, The University Centre in Svalbard, Longyearbyen, Norway \\ ${ }^{3}$ Institute for Marine and Antarctic Studies, University of Tasmania, Hobart, Tasmania, Australia \\ ${ }^{4}$ Department of Sustainability, Environment, Water, Population and Communities, Australian Antarctic Division, \\ Hobart, Tasmania, Australia \\ ${ }^{5}$ Polar Science Center, Applied Physics Laboratory, University of Washington, Seattle, WA, USA \\ ${ }^{6}$ School of Geographical Sciences, University of Bristol, Bristol, UK
}

\begin{abstract}
Freezing temperatures, desiccation and high levels of solar radiation make the surface of the Antarctic ice sheet one of Earth's harshest habitats. However, our study in the Vestfold Hills area of East Antarctica shows that favourable conditions for microbial production become established just beneath the surface of blue-ice areas, which collectively cover about $2 \%$ of the ice-sheet periphery. Their translucent, wind-polished surface allows solar heating to create meltwater in a greenhouse-type environment at depths of up to $\mathbf{1} \mathrm{m}$. Melting is intensified around dark debris particles, or cryoconite, where we found microbiological activity to be greatest. Rates of photosynthesis (average $2060 \mathrm{ng} \mathrm{C}$ (g cryoconite $\left.)^{-1} \mathrm{~d}^{-1}\right)$ were adapted to low light intensities $(\sim 10 \%$ of surface irradiance values) and most likely dominated by cyanobacteria and Chloroplastida. A heterotrophic bacterial community was also found to be active within the cryoconite, although average bacterial growth rates $(5.7 \mathrm{ng} \mathrm{C}$ (g cryoconite $^{-1} \mathrm{~d}^{-1}$ ) were far lower than average community respiration $\left(1870 \mathrm{ng} \mathrm{C}(\mathrm{g} \text { cryoconite })^{-1} \mathrm{~d}^{-1}\right)$. The majority of the respired carbon was most likely associated with the autotrophs and several protists. Therefore, blue-ice areas constitute oases for microbial life around the periphery of Earth's coldest ice sheet.
\end{abstract}

\section{INTRODUCTION}

Microorganisms are deposited across the entire Antarctic ice sheet (Vincent 1988; Carpenter and others, 2000) and their total biomass is thought to amount to about $4 \times 10^{24}$ microbial cells according to ice-core analyses (Priscu and others, 2008). This estimate, based on inland ice-core sites, is likely to be conservative since the ice-core sites are a great distance from ice-sheet margins, where there are likely to be more microorganisms in the atmosphere (see, e.g., Marshall, 1996; Pearce and others, 2009). The long-term survival of this microbial biomass following burial is of great interest for the study of isolated subglacial lakes (Priscu and others, 2008) and the hypothesized cold origin of life on Earth (Price, 2007). The discovery of viable microorganisms at the base of ice cores clearly suggests that their continued survival during slow glacial advection toward the ice-sheet margin is possible, perhaps resulting in their eventual interaction with the productive marine ecosystems after the ice sheet has lost mass into the sea. The metabolic processes required for entombed microorganisms to remain viable or even grow during transit through the Antarctic ice sheet are greatly compromised by the scarcity of liquid water (Vincent, 1988). For example, just $11.8 \%$ of Antarctica's terrestrial ice and snow surfaces are subject to summer melting (Liston and Winther, 2005). Another restriction is the harmful levels of solar radiation (including ultraviolet (UV) light), which are intensified regionally by stratospheric ozone depletion and locally by the high albedo of the ice surface. Further, since the residence time within the ice sheet can be long (up to $10^{6}$ years), older microorganisms advected down glacial flowlines can also be damaged by exposure to cosmic rays and radioactivity associated with trace mineral particles in the ice (Price, 2007). Therefore, microorganisms are subject to significant stress prior to their arrival at the ice-sheet margin, where they can become exposed at the ice surface once more by ablation, or transferred straight to the ocean by calving. Here we examine the former scenario, and consider how Antarctica's blue-ice areas are, in effect, oases of near-surface meltwater that support microbial ecosystems over much of the summer.

It has recently been argued that icy habitats supporting life in the cryosphere collectively represent a distinct biome (Hodson and others, 2008; Anesio and Laybourn-Parry, 2012). Blue-ice areas (BIAs) cover $\sim 1.7 \%\left(0.24 \times 10^{6} \mathrm{~km}^{2}\right)$ of the ice-sheet surface (Winther and others, 2001) (Fig. 1a) and represent a potential ecosystem within that biome. BIAs are formed when snow cover is removed by strong winds and/or sublimation. Consequently they exist around much of the periphery of continental Antarctica, where the katabatic winds are strongest (Fig. 1a). The marginal BIA locations are coincident with the exposure of some of Earth's oldest glacier ice upon the ice-sheet surface and also the greatest probability of meltwater production by warm air incursions. Recent modelling suggests that water fluxes of the order of $59 \times 10^{9} \mathrm{~m}^{-3} \mathrm{a}^{-1}$ result from melting in BIAs, most of which occurs $0.5-1 \mathrm{~m}$ below the ice surface (Liston and Winther, 2005). This represents about $15 \%$ of the total surface and near-surface melting that occurs on the continent, which is otherwise dominated by snowmelt occurring on its vast ice shelves. Subsurface melting predominates because strong winds remove snow cover and polish the blue-ice surface, allowing the penetration of solar radiation and the 

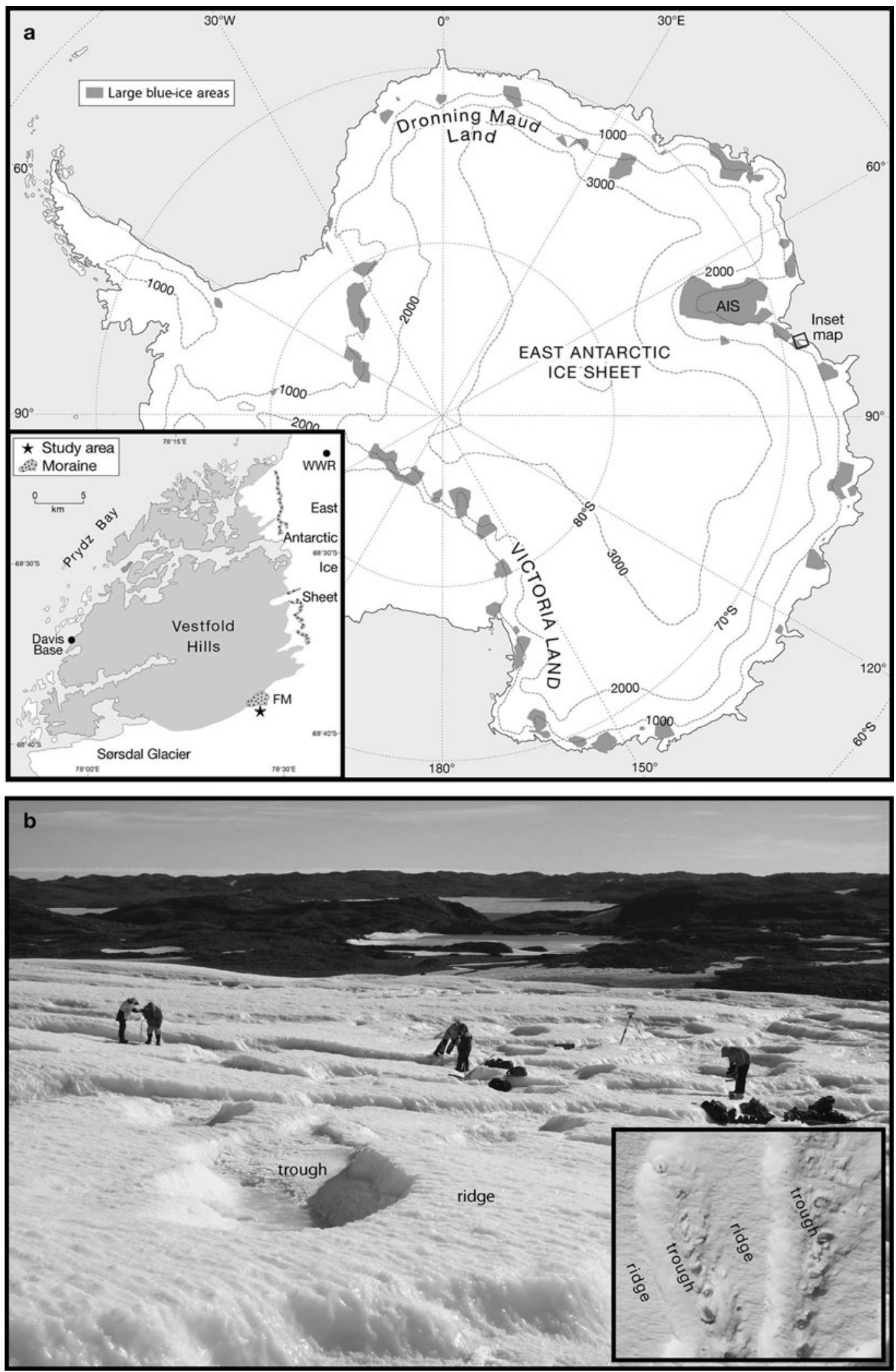

Fig. 1. (a) Blue-ice areas in Antarctica, showing the Amery Ice Shelf (AIS) near the Vestfold Hills (inset). The study site at Flanders Moraine (FM), Davis Base and Whoop Whoop Runway (WWR) are also shown. (b) The Cryoplot area being surveyed, showing the distinct ridge-andtrough morphology, including plan view (inset).

establishment of greenhouse-type conditions. These conditions are conducive to melt, especially in the vicinity of darker debris particles, which are also deposited by wind (see, e.g., Fountain and others, 2008). The result is the formation of a water- and nutrient-rich environment adjacent to the debris in a microbial habitat known as a 'cryoconite hole' (Mueller and Pollard, 2004; Tranter and others, 2004; Fountain and others, 2008; Hodson and others, 2008). Microorganisms resident within the hole are supplied from the glacier ice as the debris melts into it, and also from the surface after atmospheric deposition and meltwater transfer. At the surface, melting is infrequent, yet 
the continuous sublimation loss of ice that occurs here enables continuous melting beneath the debris at the floor of the cryoconite hole. Therefore BIA ecosystems are characterized by the mixing of microbial cells advected over timescales of $10^{4}-10^{6}$ years from the ice-sheet interior with those arriving on the surface of debris particles from icemarginal ecosystems. Both are known to include viable microorganisms (Marshall, 1996; Carpenter and others, 2000; Priscu and others, 2008; Pearce and others, 2009), yet their interaction remains completely unexplored.

Cryoconite holes are a conspicuous feature on many BIAs in continental Antarctica, especially in Dronning Maud Land (Brandt and others, 2009; Sinisalo and Moore, 2010) and on glaciers in the McMurdo Dry Valleys of Victoria Land (Wharton and others, 1981; Tranter and others, 2004; Fountain and others, 2008) (Fig. 1a). To date, only the ecology of the latter has been investigated (Christner and others, 2003; Mueller and Pollard 2004; Foreman and others, 2007). The capacity for the continental ice sheet to harbour active surface ecosystems is largely unexplored, despite the fact that a similar ecosystem is known to exist on the Greenland ice sheet (Hodson and others, 2010a; Stibal and others, 2011). This paper therefore gives specific attention to the ecology of cryoconite holes within a previously unexplored BIA of the Vestfold Hills area of the East Antarctic ice sheet (EAIS), studied during the 2008/09 austral summer. This was achieved by mapping the threedimensional distribution of cryoconite habitats on an undulating blue-ice surface, by studying the propagation of light into the blue ice and by establishing the biogeochemical conditions found within these habitats through a combination of field sampling and both in situ and laboratory-based incubations of the debris. In so doing, we were also able to establish the rates of community photosynthesis and respiration for the first time on the continental ice sheet.

\section{MATERIALS AND METHODS}

\section{Field environment}

East Antarctica's largest BIA is situated on the Amery Ice Shelf. Adjacent to the ice shelf lies a near-continuous blueice zone, which we accessed from Davis Base (Fig. 1a). Two areas of blue ice were investigated by helicopter during a reconnaissance trip: first along the flank of the westwardflowing Sørsdal Glacier, and second along the ice-sheet margin further north. The blue ice in both areas is continuous and maintained by strong katabatic airflows. However, neither debris nor subsurface melting was found at the latter site during February 2008. Instead, melting was associated with deposits of debris particles along the flank of Sørsdal Glacier in the Flanders Moraine area (Fig. 1b). Here it also likely that the advection of warm air from the Vestfold Hills increases melting, because runoff troughs and channels are a conspicuous feature (although no flowing water was observed in them during this study: Fig. 1b). The distribution, biogeochemistry and biological production of cryoconite hole habitats in the Flanders Moraine area of the Vestfold Hills were examined over a 2 week period during February 2008.

\section{Cryoconite mapping}

A combination of rapid transect survey and high-resolution mapping was employed on the ice surface in the Flanders Moraine area. For the former, the percentage of the ice surface covered by cryoconite was deduced at $30 \mathrm{~m}$ intervals along a $390 \mathrm{~m}$ transect perpendicular to the ice margin. At each point the maximum and minimum diameters of all cryoconite holes were measured in a $12.6 \mathrm{~m}^{2}$ area (defined by circle of $2 \mathrm{~m}$ radius about a randomly selected point). At the down-glacier end of the transect, a digital elevation model (DEM) of the ice surface was then produced after intensively surveying a $20 \mathrm{~m} \times 20 \mathrm{~m}$ area (hereafter the 'Cryoplot') using a Leica Total Station. All cryoconite holes were surveyed within this area in the same manner as the transect. In addition, the depths of all cryoconite within half of this area were deduced by drilling with a Kovacs ice auger. Time constraints did not allow us to drill to all the holes because field operations from Davis Base were being drawn to a close.

The light environment of the Cryoplot was established using two Skye Instruments pyranometers: one $\sim 0.5 \mathrm{~m}$ above the ice surface and one installed on the surface of a $\sim 84 \mathrm{~cm}$ deep cryoconite debris layer, initially submerged beneath $20 \mathrm{~cm}$ water, an air gap and then a surface ice lid $\sim 5 \mathrm{~cm}$ thick. Both instruments measured incident radiation (400-1200 nm) in $\mathrm{W} \mathrm{m}^{-2}$, which was also used to estimate photosynthetically active radiation (PAR: $400-700 \mathrm{~nm}$ ) for these locations using an empirical relationship established with a LiCor LI-192SA PAR sensor. In addition, the PAR sensor was used to derive six light profiles at $5 \mathrm{~cm}$ intervals after drilling a $7 \mathrm{~cm}$ diameter hole down $150 \mathrm{~cm}$ into the ice with a Kovacs auger. Profiles were measured during peak daily irradiance at solar noon. In order to consider the effects of light reflection down the open hole, the profiles were measured with and without an opaque cap over the hole. Three holes were drilled on exposed ice ridge tops and three in shallow troughs where a thin snow layer had accumulated (e.g. Fig. 1b).

Air temperature, wind speed and wind direction data were supplied courtesy of the Australian Antarctic Division for two locations: Davis Base (18 ma.s.l.) and Whoop Whoop Airfield (550 ma.s.I.) on the ice-sheet plateau east of the base. An air temperature record was then constructed for the study site $(150 \mathrm{~m}$ a.s.l.) by interpolation between these two locations.

\section{Biogeochemistry}

Sampling was conducted within the Cryoplot during its survey (12 cryoconite water samples and 10 glacier ice samples), and at every cryoconite hole before biological production measurements were taken (see below). The subsequent analyses were used to assess the dissolved oxygen $\left(\mathrm{DO}_{2}\right)$, total dissolved inorganic carbon (TDIC) and major-ion $\left(\mathrm{Ca}^{2+}, \mathrm{Mg}^{2+}, \mathrm{Na}^{+}, \mathrm{K}^{+}, \mathrm{F}^{-}, \mathrm{Cl}^{-}, \mathrm{NO}_{3}{ }^{-}\right.$and $\left.\mathrm{SO}_{4}{ }^{2-}\right)$ concentrations. The $\mathrm{pH}$ measurements were discarded owing to poor performance of the electrode in the cold. TDIC was analysed using the headspace method after acidification of $15 \mathrm{~mL}$ samples with $5 \% \mathrm{HCl}$ immediately upon return from the field and as described in full by Hodson and others (2010b). Otherwise, all samples were filtered through a $0.2 \mu \mathrm{m}$ membrane and frozen prior to analysis in the United Kingdom using Dionex DX90 ion chromatography for ions and a Thermalox TC/TN analyser for dissolved organic carbon (DOC). Precision errors were $10 \%$ or less for DOC (calibration range $1-10 \mathrm{mg} \mathrm{L}^{-1}$ ), $5 \%$ or less for $\mathrm{DO}_{2}$ and the ion determinations (detection limit $1 \mu \mathrm{g} \mathrm{L}^{-1}$ and calibration range $0-2 \mathrm{mg} \mathrm{L}^{-1}$ ) and $3 \%$ or less for TDIC. DOC assays were only conducted on the 12 Cryoplot samples. 


\section{In situ measurements of primary production and respiration}

Batch incubations were undertaken at 12 sites following the precise methodology developed by Hodson and others (2010a). This is based on the long-established use of light and dark flask incubations for assessing net ecosystem production (NEP) and respiration $(R)$ respectively. Primary production (PP) can then be estimated by difference (between batch averages) since:

$$
\mathrm{NEP}=\mathrm{PP}-R \text {. }
$$

The terms NEP and $R$ were estimated using the TDIC change ( $\triangle \mathrm{TDIC}$ ) of the light and dark incubations after correction for the production of TDIC from carbonate weathering. Therefore:

$$
\begin{gathered}
\mathrm{NEP}^{\mathrm{TDIC}}=\mathrm{TDIC}^{\text {light }}-[\mathrm{Ca}]^{\text {light }} \\
R^{\text {TDIC }}=\Delta \mathrm{TDIC}^{\text {dark }}-[\mathrm{Ca}]^{\text {dark }} \\
\mathrm{PP}^{\mathrm{TDIC}}=\left(\Delta \mathrm{TDIC}^{\text {light }}-[\Delta \mathrm{Ca}]^{\text {light }}\right)-R^{\text {TDIC }}
\end{gathered}
$$

where $[\Delta \mathrm{Ca}]$ represents the production of TDIC by carbonate weathering $(1 \mu \mathrm{M}(12 \mu \mathrm{g})$ of TDIC per $\mu \mathrm{M}$ $(41 \mu \mathrm{g})$ of $\left.\mathrm{Ca}^{2+}\right)$ during the incubations.

At each site, six large UV-transparent Whirl-Pak ${ }^{\circledR}$ bags were carefully filled with $\sim 20 \mathrm{~g}$ of cryoconite debris and $350 \mathrm{~mL}$ of cryoconite hole water. Three of them were foilwrapped for dark incubation, and all of them were placed back in a cryoconite hole for 1-3 days incubation. Then $15 \mathrm{~mL}$ gas-tight Eppendorf tubes were filled with incubation solution and analysed immediately after return to the laboratory for TDIC using the headspace method. The DO was also measured three times in the field using a luminescence meter (Hach LDO) and further $15 \mathrm{~mL}$ samples taken for major-ion determination in the United Kingdom. Changes in all chemical conditions were deduced by subtraction of the initial incubation conditions and then normalized for the dry mass of cryoconite used after ovendrying the debris at $40^{\circ} \mathrm{C}$. Combustion at $450^{\circ} \mathrm{C}$ for 4 hours was then used to assess the total organic carbon content through the loss on ignition (LOI) method. Additionally, the chlorophyll-a concentration of the debris was established spectrophotometrically after methanol extraction in the dark at $-20^{\circ} \mathrm{C}$ (Talling, 1969).

\section{Laboratory determinations of primary and bacterial production}

Incubations using the above methods were also repeated in an environment chamber at $1{ }^{\circ} \mathrm{C}$ using cryoconite waters and samples collected from the field and incubation waters with lower $\mathrm{DO}_{2}$ levels than those encountered in the field. The purpose of this was to remove the problem of high ambient $\mathrm{DO}_{2}$ levels caused by photosynthesis and freeze-concentration (see below) and to examine rates of PP under controlled (artificial) light conditions. Large samples of cryoconite hole waters were allowed to equilibrate to the laboratory atmosphere at $18^{\circ} \mathrm{C}$ (causing the surplus $\mathrm{DO}_{2}$ to degas) and were then sealed, chilled to $1{ }^{\circ} \mathrm{C}$ and added to the incubations. This process had no significant effect upon the TDIC of the initial solution used to commence the incubations (which was between 0.7 and $1.1 \mathrm{mg} \mathrm{CL}^{-1}$ and therefore in the same range as the in situ incubations). However, the $\mathrm{DO}_{2}$ was $\sim 40 \%$ lower than in the field (average $10 \mathrm{mg} \mathrm{L}^{-1}$ ) and far more stable during the initial handling of the solutions and debris. Four light incubations were therefore conducted at $100 \mu \mathrm{mol} \mathrm{m}^{-2} \mathrm{~s}^{-1}$ PAR and a further two at $75 \mu \mathrm{mol} \mathrm{m} \mathrm{m}^{-2} \mathrm{~s}^{-1}$ for a duration of 5 and 3 days respectively. Foil-wrapped dark incubations were also conducted at the same time.

Finally, rates of gross photosynthesis and light curve characteristics were also deduced using short-term laboratory incubations of six fresh ${ }^{14} \mathrm{C}-\mathrm{HCO}_{3}{ }^{-}$-labelled cryoconite water and debris samples at 21 irradiance levels between 0 and $485 \mu \mathrm{mol} \mathrm{m} \mathrm{m}^{-2} \mathrm{~s}^{-1}$ and following the exact methods reported by Westwood and others (2010). Briefly, $7 \mathrm{~mL}$ working solutions of $\mathrm{NaH}^{14} \mathrm{CO}_{3}$ with an activity of $39.183 \times 10^{3} \mathrm{~Bq} \mathrm{~mL}^{-1}\left(1.1 \mu \mathrm{C} \mathrm{mL}^{-1}\right)$ were inoculated with $2 \mathrm{~mL}$ of sample in a transparent glass scintillation vial and incubated for 1 hour at $1{ }^{\circ} \mathrm{C}$. This was done immediately after returning from the field using samples that were less than 3 hours old. Light curve parameters were defined statistically after estimating the photosynthesis using the protocols described by Platt and others (1980).

Bacterial production was determined for debris from 12 cryoconite holes using the micro-centrifuge method of Kirchman (2001). These measurements were conducted immediately on return to the laboratory. $\left[{ }^{14} \mathrm{C}\right]$ leucine (specific activity $86 \mathrm{Cimmol}^{-1}$ ) was added to triplicate $2.0 \mathrm{~mL}$ samples to a final concentration of $35 \mathrm{nM}$ and incubated at $1^{\circ} \mathrm{C}$ for $90 \mathrm{~min}$. One control sample was killed with $90 \mu \mathrm{L}$ of $100 \%$ trichchloroacetic acid (TCA) and labelled leucine added as above. Incubations were terminated by the addition of $90 \mu \mathrm{L}$ of $100 \%$ TCA. Tubes were centrifuged at $16000 \times g$ for $10 \mathrm{~min}$ and the supernatant aspirated. Then $1.7 \mathrm{~mL}$ of ice-cold $5 \%$ TCA was added to each tube and the centrifugation procedure repeated. The TCA was aspirated and $1.7 \mathrm{~mL}$ of ice-cold ethanol added and a further centrifugation step performed. The final supernatant was aspirated and $1 \mathrm{~mL}$ of scintillation cocktail added prior to counting in a Beckman LS6500 scintillation counter. For the calculation of bacterial production we used an intracellular dilution factor of 2, leucine/protein ratio of 0.073 and a carbon/protein ratio of 0.86 (Smith and Azam, 1992).

\section{Microbial enumeration}

Accurate enumeration of eukarya and bacteria associated with cryoconite is notoriously difficult because of the problems associated with masking by debris. Therefore indicative numbers of these microorganisms were sought using a combination of flow cytometry and epifluorescence microscopy. Phytoplankton and cyanobacteria were therefore enumerated in four of the water samples and eight of the debris suspensions immediately after sampling for the bacterial production measurements. They were screened through a $50 \mu \mathrm{m}$ mesh immediately after sampling and analysed using a FACScan flow cytometer (Becton Dickinson) with a $488 \mathrm{~nm}$ argon laser. Samples were chilled in an ice-filled beaker and analysed for $5 \mathrm{~min}$ at a flow rate of

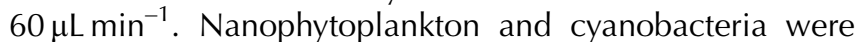
discriminated using their red and orange autofluorescence respectively, using bivariate scatter plots of red versus orange fluorescence (FL3 and FL2 respectively). Samples were weighed with $\pm 0.0001 \mathrm{~g}$ accuracy before and after each run to determine the volume analysed. Concentrations of microbes were then calculated using event counts from bivariate scatter plots and the volume analysed. Ten microlitres of PeakFlow Green $2.5 \mu \mathrm{m}$ beads (molecular probes) were added to all samples as an internal standard. 
Enumeration of bacteria in eight samples (four debris and four water) was undertaken using $2 \mathrm{~mL}$ samples of debris suspension fixed in buffered glutaradehyde (final concentration $2 \%$ ), stained with SYBR Gold, filtered on to $0.2 \mu \mathrm{m}$ black polycarbonate filter and counted using an epifluorescence microscope. SYBR Gold stained the bacteria very strongly in the sediment suspensions, making them clearly visible. However, as experienced elsewhere (e.g. Langford and others, 2010), masking by the debris means that the bacterial counts are for indicative purposes only.

\section{RESULTS}

Figure 2 shows the meteorological conditions encountered during the study. Air temperatures were only briefly above $0^{\circ} \mathrm{C}$ on day of year (DOY) 51-52. However, while this caused meltwater to flow in the streams at the immediate ice margin, no such flows were observed on the Cryoplot and further away from the margin. Figure $2 b$ shows that clear diurnal cycles in incident solar radiation persisted throughout the study, but were influenced by a period of cloud cover later in the study on DOYs 55 and 56. Wind speeds were also greatest during this period (Fig. 2c), although high wind speeds also occurred on DOYs 50 and 52. On all these occasions, the wind directions were $20-60^{\circ}$, representing typical katabatic air transfers down the ice sheet according to a long-term analysis of data from Davis Base by Adams (2008) (Fig. 3). The stronger winds on DOY 55 led to the deposition of fine debris over the Cryoplot, which must have been of very local origin because the katabatic airflows descending from the plateau only encounter debris immediately upwind of the study site. Such winds are therefore far more likely to bring snow than debris (Fig. 3b). Strong winds blowing directly onto the glacier from the Vestfold Hills (i.e. from the northwest quadrant) were not witnessed during fieldwork, and the analysis of historical records by Adams (2008) shows that this is clearly due to the dominance of katabatic airflow.

\section{Habitat distribution along the transect and within the Cryoplot}

Up to $16 \%$ of the ice surface along the transect was occupied by cryoconite holes between 1 and $40 \mathrm{~cm}$ diameter (average $12.3 \mathrm{~cm}$, standard deviation $14.0 \mathrm{~cm}$ and therefore of area up to $2500 \mathrm{~cm}^{2}$ ) (Fig. 4a). Very clear exponential decreases in the percentage cover, average size and standard deviation of size occurred with distance from the ice margin (Fig. $4 \mathrm{a}-\mathrm{C}$ ). A linear increase in the number of cryoconite holes also occurred along the transect, but was rendered insignificant at $p<0.05$ owing to two outliers (Fig. 4d). Figure $5 \mathrm{a}$ shows that, in spite of this strong distance-decay in cryoconite hole cover, there was no relationship between cryoconite hole location and ice surface topography. Therefore, at smaller spatial scales, such as within the Cryoplot, the cryoconite holes appear juxtaposed upon an undulating ice surface composed of ridges of troughs in a random pattern. However, the depth of the cryoconite hole beneath the ice surface did vary significantly, resulting in a bimodal distribution of depth (Fig. 5b). The first mode $(30-40 \mathrm{~cm})$ was exclusively related to holes beneath troughs, while the second $(60-70 \mathrm{~cm})$ was associated with the ridge-top holes. All cryoconite holes were covered by an ice lid 5-20 cm thick. However, it was notable that the ice lids were level with the ice surface in the
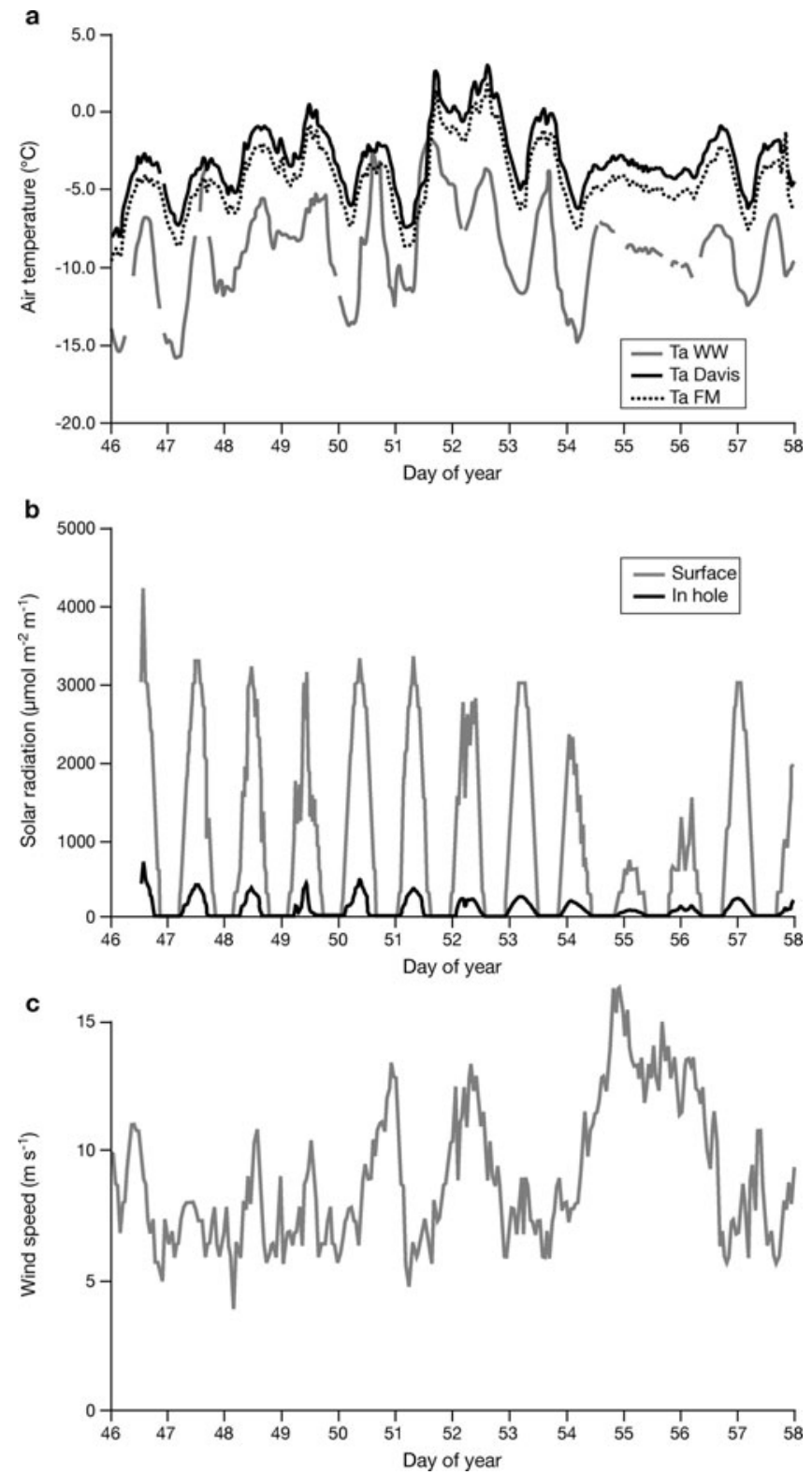

Fig. 2. (a) Air temperature $\left(T_{\mathrm{a}}\right)$ variations during the study at Davis Base (Davis: $18 \mathrm{~m}$ ), Whoop Whoop Runway (WW: $550 \mathrm{~m}$ ) and Flanders Moraine (FM: $110 \mathrm{~m}$ ). (b) Incident radiation at the ice surface and inside a cryoconite hole beneath an ice lid. (c) Wind speed variations at Davis Base.

case of the deeper ridge community, while those in the troughs were nearly always lower than the surrounding ice, indicating drainage prior to ice lid formation. This contributed to the efficacy of snow collection within the troughs and valleys, making it thicker there and causing self-shading of the larger holes. Barely any snow cover persisted upon the ridges, there being none at all when ablation was occurring. In all environments, snow cover was dominated by small $(<2 \mathrm{~mm})$ particles whose form was indicative of saltation and damage in transit over the rough ice surface.

\section{Light and climate conditions during the study}

Solar radiation received at the surface of the debris in the $84 \mathrm{~cm}$ deep instrumented ridge-top cryoconite hole (Fig. 2b) represented up to $14 \%$ (average $9.16 \%$ ) of surface irradiance throughout the study. The pyranometer data suggest that average PAR receipt at the ice surface was $409 \mu \mathrm{mol} \mathrm{m}^{-2} \mathrm{~s}^{-1}$ 


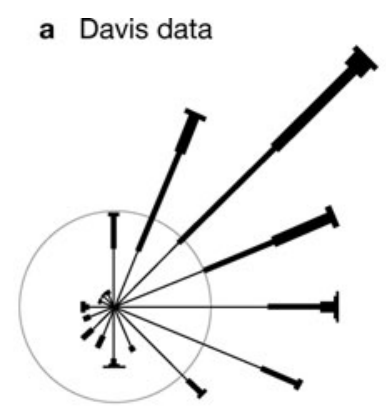

b Particle vectors

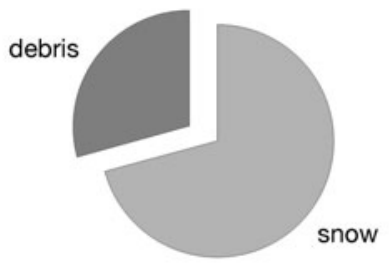

c Whoop Whoop data

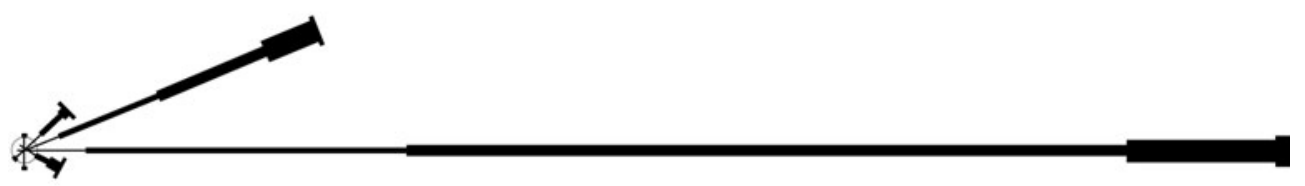

Key to a and c

$\begin{array}{llllll}0-5 & 5-10 & 10-20 & 20-30 & 30-40 \quad>40 \quad \mathrm{~m} \mathrm{~s}^{-1}\end{array}$

$10 \%$ of observations. (Radius of circle defines percentage of calm observations)

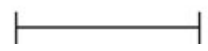

Fig. 3. Wind directions at Davis Base (a) and Whoop Whoop (c) according to a historical analysis by Adams (2008). Vectors for debris and snow-drift transfer by wind to the study site are also shown (b).

a

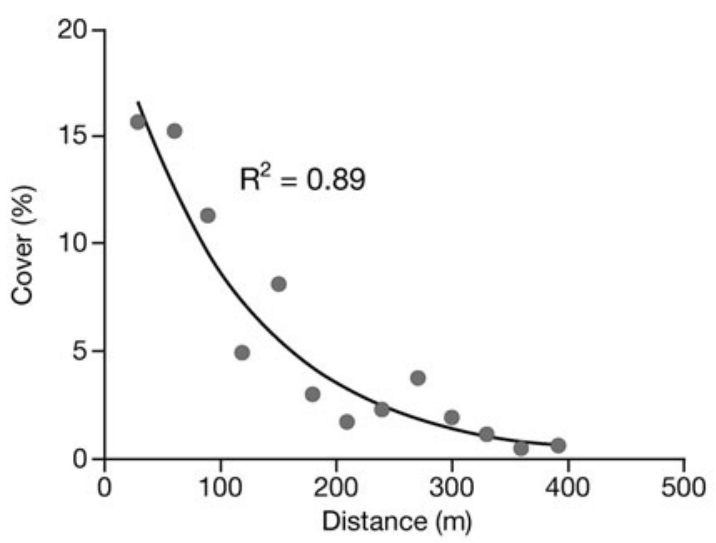

c

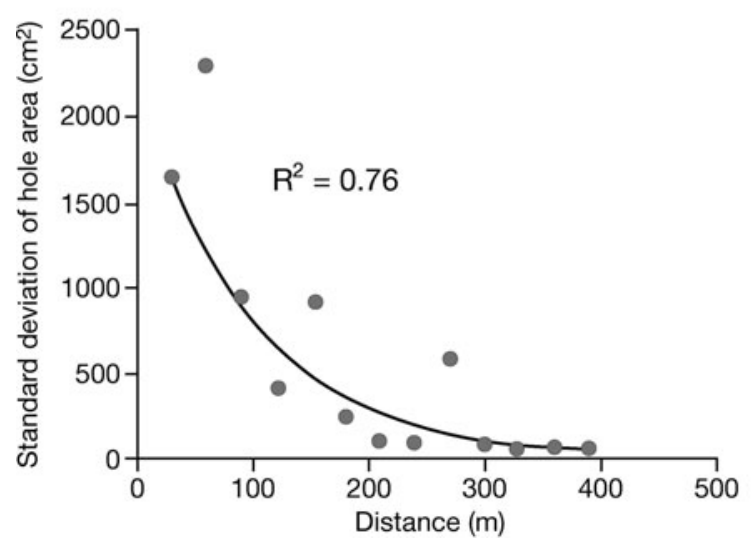

b

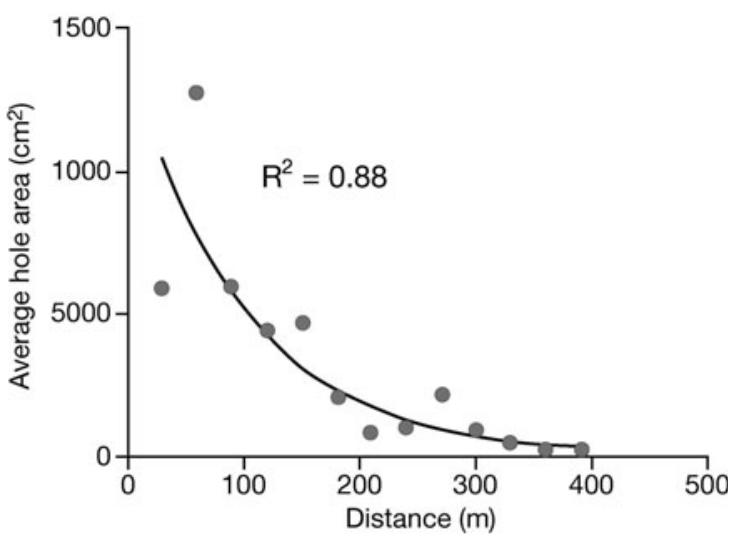

d

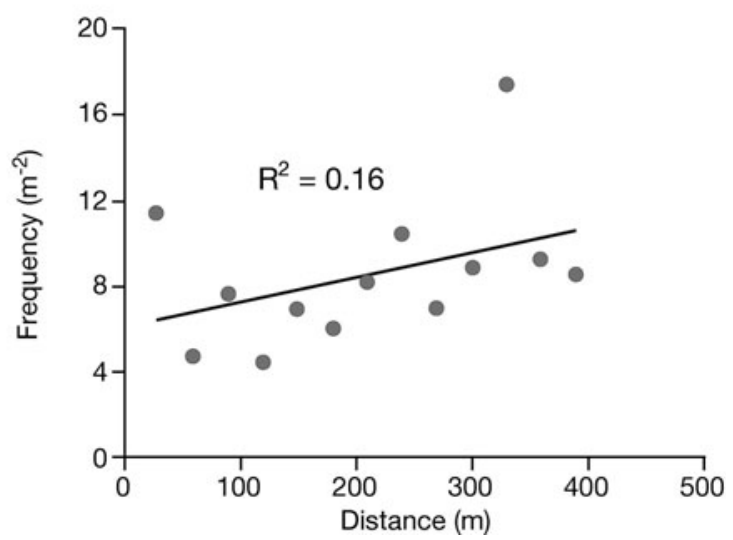

Fig. 4. Characteristics of cryoconite cover with increasing distance from the ice margin along a north-south transect from Flanders Moraine: (a) the percentage of the ice covered by cryoconite holes; (b) average cryoconite hole area; (c) standard deviation of cryoconite hole area; and (d) cryoconite hole frequency. 


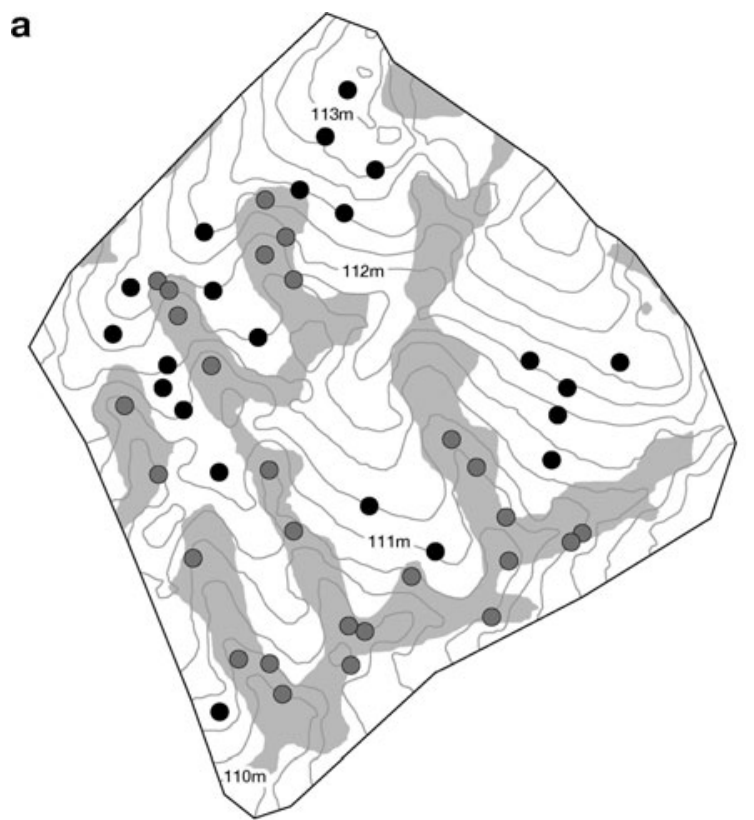

b

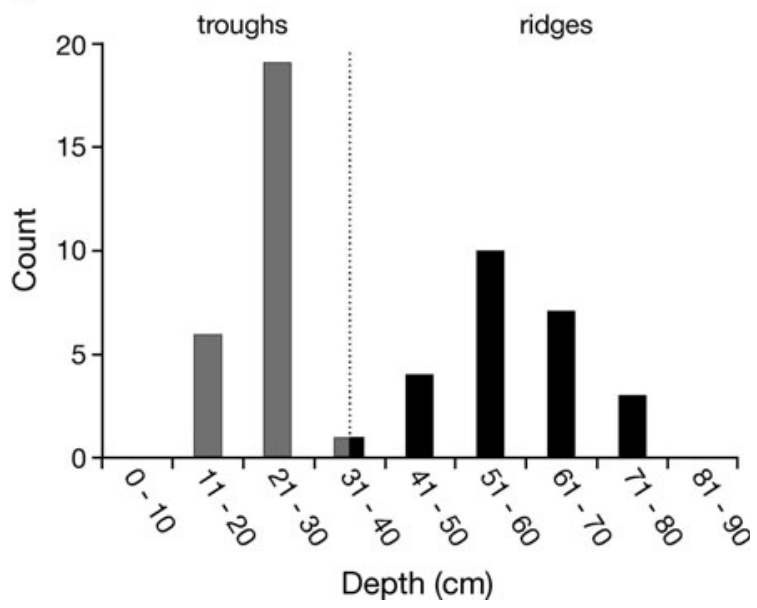

Fig. 5. The position of cryoconite holes within the Cryoplot: (a) plan view showing $20 \mathrm{~cm}$ ice surface contours (shaded area shows the troughs); (b) the bimodal distribution of cryoconite hole depths that results from distinct ridge and trough populations. Black and grey circles show cryoconite holes on ridges and in troughs respectively.

(maximum $1860 \mu \mathrm{mol} \mathrm{m} \mathrm{m}^{-2} \mathrm{~s}^{-1}$ ), while in the cryoconite hole it was $37 \mu \mathrm{mol} \mathrm{m}^{-2} \mathrm{~s}^{-1}$ (maximum $302 \mu \mathrm{mol} \mathrm{m}^{-2} \mathrm{~s}^{-1}$ ).

PAR profiles into the ridges and valleys showed quasiexponential extinction curves at all sites (Fig. 6). However, the proportion of surface PAR irradiance penetrating the ice was greatly reduced beneath the valleys. The average percentage of PAR incident at the modal depth values for cryoconite beneath ridges and valleys (i.e. at $65 \mathrm{~cm}$ and $35 \mathrm{~cm}$ respectively, according to Fig. 5b) was $11.5 \%$ and $9.07 \%$ respectively. It should be noted that reflection down the hole walls was apparent in the profiles when the measurements were repeated with the opaque cap, especially in the upper $80 \mathrm{~cm}$ of the profile (data not shown). The implications of this are explored in the discussion.

\section{Biogeochemical conditions in cryoconite holes}

Table 1 shows the biogeochemical conditions within the cryoconite holes sampled immediately after their ice lids were broken. Water temperatures were almost always $\sim 0.1^{\circ} \mathrm{C}$, so the high $\mathrm{DO}_{2}$ conditions reveal saturation in

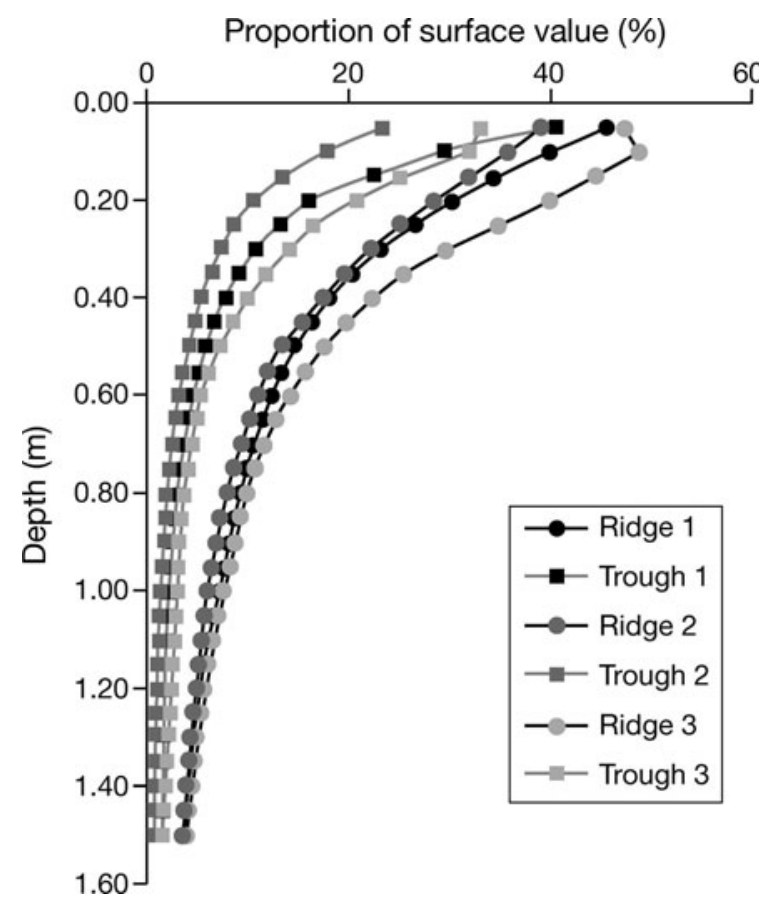

Fig. 6. Photosynthetically active radiation profiles with depth for three ridge-top and four trough profiles.

almost all holes. In fact, just one (H10) was under-saturated with respect to atmospheric equilibrium. This was the largest cryoconite hole sampled during the study, which was also notable for a higher TDIC concentration $\left(1.5 \mathrm{mg} \mathrm{CL}^{-1}\right)$ relative to average concentrations $\left(0.84 \mathrm{mg} \mathrm{C} \mathrm{L}^{-1}\right)$. However, TDIC concentrations were exceeded by DOC concentrations in the hole waters (average $1.40 \mathrm{mg} \mathrm{CL}^{-1}$ ) and were far lower than the TDIC levels found in glacier ice (average $1.41 \mathrm{mg} \mathrm{CL}^{-1}$ ). The cryoconite waters are therefore notable for their low ionic strength and otherwise appear dominated by $\mathrm{Ca}^{2+}, \mathrm{SO}_{4}{ }^{2-}, \mathrm{Na}^{+}$and $\mathrm{Cl}^{-}$(Table 1$)$. When corrected for marine salts using standard marine ratios (Drever, 1997) only the residual quantities of $\mathrm{Ca}^{2+}, \mathrm{Mg}^{2+}$ and $\mathrm{SO}_{4}{ }^{2-}$ were significant (data not shown). The non-marine $\mathrm{Mg}^{2+}$ showed strong covariance with non-marine $\mathrm{SO}_{4}{ }^{2-}$ but not with nonmarine $\mathrm{Ca}^{2+}$, suggesting that only the latter was produced by carbonate weathering. An additional source of solute is therefore required to explain these ions, and the most likely explanation is an efflorescent salt.

The chemistry of ten glacier ice samples collected while drilling at the Cryoplot is also presented in Table 1. Their similar composition to the hole waters is immediately apparent and reveals the importance of ice wall melting in the supply of water and solutes to the cryoconite habitats. In most cases, average solute concentrations of the holes are between one and two times that of the ice (data not shown). However, the average hole water concentrations are depleted in $\mathrm{NH}_{4}{ }^{+}$, while the $\mathrm{SO}_{4}{ }^{2-}$ concentrations are far more enriched than the other solutes. This further supports the assertion that geochemical processes other than freeze concentration occur in these holes.

\section{Microbiology and in situ biological production}

Table 2 shows that microalgae, cyanobacteria and other bacteria were present in the Vestfold Hills cryoconite holes according to the flow cytometry and epifluorescence microscopy. The total numbers of bacteria far exceeded 
Table 1. Biogeochemical conditions in cryoconite hole waters and glacier ice. All units are $\mathrm{mg} \mathrm{L}^{-1}$. $\mathrm{DO}_{2}$ is dissolved oxygen content, TDIC is total dissolved inorganic carbon content and DOC is dissolved organic carbon content. 'n.d.' means not determined

\begin{tabular}{|c|c|c|c|c|c|c|c|c|c|c|c|c|}
\hline ID & $\mathrm{Na}$ & $\mathrm{NH}_{4}$ & $\mathrm{~K}$ & $\mathrm{Mg}$ & $\mathrm{Ca}$ & $\mathrm{F}$ & $\mathrm{Cl}$ & $\mathrm{SO}_{4}$ & $\mathrm{NO}_{3}$ & $\mathrm{DO}_{2}$ & TDIC & DOC \\
\hline \multicolumn{13}{|c|}{ Cryoconite hole waters } \\
\hline $\mathrm{H} 2$ & 1.106 & 0.014 & 0.140 & 0.186 & 0.563 & 0.000 & 1.778 & 0.562 & 0.067 & 15.1 & 0.53 & 0.23 \\
\hline $\mathrm{H} 3$ & 1.157 & 0.347 & 0.294 & 0.230 & 1.582 & 0.118 & 2.066 & 1.825 & 0.040 & 14.7 & 0.72 & 2.41 \\
\hline $\mathrm{H} 4$ & 0.673 & 0.046 & 0.246 & 0.194 & 2.139 & 0.138 & 1.111 & 1.585 & 0.000 & 14.4 & 1.01 & 2.5 \\
\hline H6 & 1.396 & 0.048 & 0.560 & 0.193 & 0.566 & 0.226 & 2.350 & 0.700 & 0.035 & 16.3 & 0.76 & 1.5 \\
\hline $\mathrm{H} 7$ & 1.042 & 0.114 & 0.758 & 0.145 & 0.643 & 0.393 & 1.786 & 0.457 & 0.142 & 19.1 & 0.72 & 2.1 \\
\hline H8 & 3.266 & 0.044 & 0.594 & 0.411 & 0.600 & 0.267 & 5.533 & 0.945 & 0.113 & 17.7 & 0.78 & 1.82 \\
\hline $\mathrm{H} 9$ & 0.640 & 0.024 & 0.265 & 0.128 & 0.714 & 0.115 & 1.088 & 0.530 & 0.035 & 18.0 & 0.90 & 0.96 \\
\hline $\mathrm{H} 10$ & 1.079 & 0.057 & 0.368 & 0.173 & 0.627 & 0.116 & 1.913 & 0.679 & 0.000 & 11.5 & 1.50 & 1.79 \\
\hline $\mathrm{H} 11$ & 1.436 & 0.010 & 0.347 & 0.248 & 0.753 & 0.000 & 2.446 & 0.391 & 0.206 & 16.5 & 0.69 & 0.6 \\
\hline $\mathrm{H} 12$ & 0.875 & 0.063 & 0.257 & 0.164 & 0.743 & 0.177 & 1.431 & 0.591 & 0.099 & 16.5 & 0.67 & 1.31 \\
\hline i1 & 0.818 & 0.315 & 0.334 & 0.157 & 0.544 & 0.000 & 1.265 & 0.179 & 0.039 & n.d. & 1.67 & n.d. \\
\hline i2 & 0.818 & 0.324 & 0.336 & 0.155 & 0.536 & 0.014 & 1.275 & 0.178 & 0.037 & n.d. & 1.65 & n.d. \\
\hline i3 & 0.812 & 0.064 & 0.324 & 0.143 & 0.530 & 0.047 & 1.290 & 0.223 & 0.054 & n.d. & 0.566 & n.d. \\
\hline i4 & 0.790 & 0.339 & 0.303 & 0.158 & 0.636 & 0.000 & 1.304 & 0.214 & 0.052 & n.d. & 1.85 & n.d. \\
\hline ¡5 & 0.286 & 0.010 & 0.030 & 0.060 & 0.870 & 0.000 & 0.391 & 0.115 & 0.041 & n.d. & 2.18 & n.d. \\
\hline i6 & 0.291 & 0.013 & 0.034 & 0.063 & 0.955 & 0.000 & 0.392 & 0.115 & 0.041 & n.d. & 2.47 & n.d. \\
\hline i7 & 0.521 & 0.024 & 0.087 & 0.107 & 0.495 & 0.000 & 0.776 & 0.195 & 0.054 & n.d. & 0.646 & n.d. \\
\hline i8 & 0.513 & 0.024 & 0.099 & 0.093 & 0.282 & 0.032 & 0.767 & 0.201 & 0.058 & n.d. & n.d. & n.d. \\
\hline i9 & 0.674 & 0.008 & 0.037 & 0.143 & 0.329 & 0.000 & 1.008 & 0.308 & 0.066 & n.d. & n.d. & n.d. \\
\hline i10 & 0.685 & 0.000 & 0.054 & 0.164 & 0.496 & 0.013 & 1.014 & 0.306 & 0.060 & n.d. & 0.240 & n.d. \\
\hline
\end{tabular}

the number of microalgae and cyanobacteria, especially in the case of the debris. In the water, far fewer types of all cells were encountered. For example, no cyanobacteria were detected in the water samples. Flow cytometry has yet to become a standard method for the study of cryoconite microbial communities. However, estimates of bacterial biomass from epifluorescence microscopy are more common, so our results are compared with a worldwide selection of data in the discussion below.

Table 3 shows the estimates of NEP, $R$ and PP derived from the field incubations. Values normalized for the dry mass of debris range across an order of magnitude in the case of respiration $\left.(0.46-4.5 \mu \mathrm{gC} \text { (g cryoconite })^{-1} \mathrm{~d}^{-1}\right)$ and slightly less in the case of photosynthesis $(0.61-4.82 \mu \mathrm{g}$ C (g cryoconite $\left.)^{-1} \mathrm{~d}^{-1}\right)$. A strong, positive correlation $\left(r^{2}=0.96\right.$, $p<0.05$ ) between PP and $R$ was also found with a slope that was not significantly different from 1 (Fig. 7). Other statistically significant chemical changes noted in the incubations included $\mathrm{NH}_{4}^{+}$production by dark respiration that was correlated to both respiration $\left(r^{2}=0.71\right)$ and LOI $\left(r^{2}=0.83\right)$. This pattern was also observed during dark incubations in the

Table 2. Indicative average numbers of nanophytoplankton, cyanobacteria and total bacteria according to flow cytometry and epifluorescence microscopy respectively

\begin{tabular}{|c|c|c|c|}
\hline Type & Method & $\begin{array}{l}\text { Water cells } \\
10^{3} \mathrm{~mL}^{-1}\end{array}$ & $\begin{array}{l}\text { Debris slurry cells } \\
\qquad 10^{3} \mathrm{mg}^{-1}\end{array}$ \\
\hline $\begin{array}{l}\text { Microalgae } \\
\text { Cyanobacteria } \\
\text { Total bacteria }\end{array}$ & $\begin{array}{c}\text { Flow cytometry } \\
\text { Flow cytometry } \\
\text { Microscopy }\end{array}$ & $\begin{array}{c}0.044 \pm 0.035 \\
\text { no data } \\
0.26 \pm 0.19\end{array}$ & $\begin{array}{c}9.3 \pm 8.2 \\
8.8 \pm 6.9 \\
3800 \pm 2500\end{array}$ \\
\hline
\end{tabular}

laboratory. Finally, the $\mathrm{DO}_{2}$ changes were not significantly correlated with TDIC changes in either the light or the dark incubations, which was most likely due to the supersaturation of $\mathrm{O}_{2}$ in the initial solutions.

\section{Laboratory determinations of biological production}

Rates of photosynthesis (PP) conducted under 100 and $75 \mu \mathrm{mol} \mathrm{m} \mathrm{m}^{-2} \mathrm{~s}^{-1}$ PAR ranged from 4.31 to $9.17 \mu \mathrm{g} \mathrm{C}$ (g cryoconite $)^{-1} \mathrm{~d}^{-1}$ and were therefore significantly greater than the field incubations described above (Table 3). Figure 7 also shows that the relationship between PPand $R$ was identical to that observed in the field, in spite of their longer incubations.

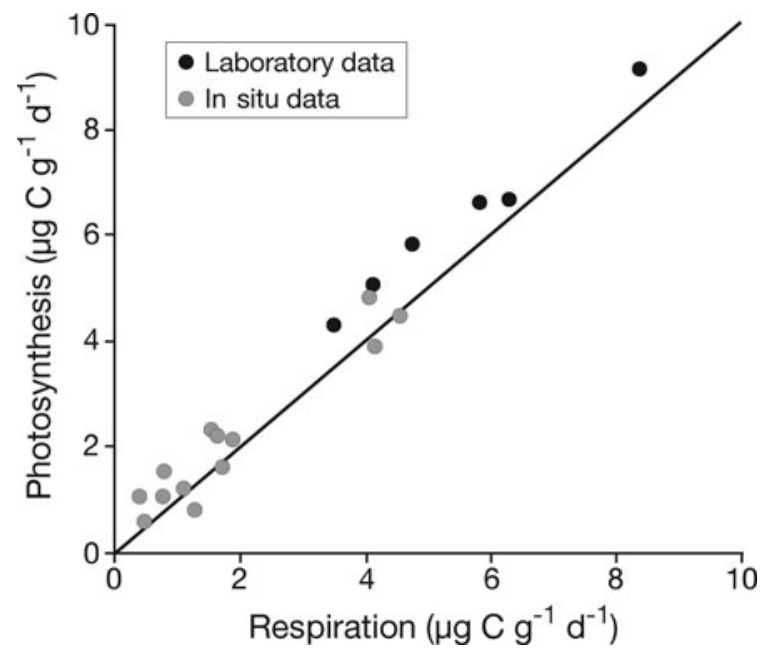

Fig. 7. The relationship between photosynthesis (PP) and respiration (R) established using the values for in situ and laboratory incubations in Table 3. Values are normalized for the dry mass of cryoconite. 
Table 3. Average measured net ecosystem production (NEP), respiration $(R)$ and calculated photosynthesis (PP) deduced from the light and dark incubations conducted in situ and in the laboratory. Average PAR receipt at the ice surface and also inside the instrumented cryoconite hole is also shown (PAR ${ }^{\text {surface }}$ and PAR $^{\text {in situ }}$ respectively)

\begin{tabular}{|c|c|c|c|c|c|c|}
\hline ID & $\begin{array}{c}\text { LOI } \\
\%\end{array}$ & $\begin{array}{c}\text { NEP } \\
\mu \mathrm{g} \mathrm{Cg}^{-1} \mathrm{~d}^{-1}\end{array}$ & $\begin{array}{c}R \\
\mu g \mathrm{Cg}^{-1} \mathrm{~d}^{-1}\end{array}$ & 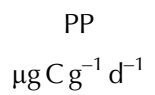 & $\begin{array}{c}\text { PAR }^{\text {surface }} \\
\mu \mathrm{mol} \mathrm{m}^{-2} \mathrm{~s}^{-1}\end{array}$ & $\begin{array}{c}\text { PAR }^{\text {in situ }} \\
\mu \mathrm{mol} \mathrm{m}^{-2} \mathrm{~s}^{-1}\end{array}$ \\
\hline
\end{tabular}

\begin{tabular}{|c|c|c|c|c|c|c|}
\hline \multicolumn{7}{|c|}{ In situ incubations } \\
\hline $\mathrm{H} 1$ & 0.76 & $0.30 \pm 0.24$ & $0.75 \pm 0.13$ & 1.06 & 283 & 31 \\
\hline $\mathrm{H} 2$ & 0.61 & $-0.47 \pm 0.13$ & $1.26 \pm 0.46$ & 0.79 & 283 & 38 \\
\hline $\mathrm{H} 3$ & 0.68 & $0.12 \pm 0.21$ & $1.09 \pm 0.21$ & 1.20 & 457 & 81 \\
\hline $\mathrm{H} 4$ & 1.10 & $0.76 \pm 0.19$ & $0.78 \pm 0.18$ & 1.54 & 457 & 81 \\
\hline $\mathrm{H} 5$ & 0.98 & $0.15 \pm 0.09$ & $0.46 \pm 0.18$ & 0.61 & 457 & 81 \\
\hline H6 & 1.56 & $-0.26 \pm 0.05$ & $4.15 \pm 0.58$ & 3.90 & 457 & 81 \\
\hline $\mathrm{H} 7$ & 1.49 & $0.76 \pm 0.11$ & $4.06 \pm 0.09$ & 4.82 & 497 & 89 \\
\hline H8 & 1.34 & $0.75 \pm 0.50$ & $1.55 \pm 0.14$ & 2.30 & 497 & 89 \\
\hline $\mathrm{H} 9$ & 1.38 & $0.58 \pm 0.25$ & $1.63 \pm 1.10$ & 2.21 & 497 & 89 \\
\hline $\mathrm{H} 10$ & 2.00 & $-0.06 \pm 0.62$ & $4.54 \pm 1.98$ & 4.48 & 497 & 89 \\
\hline $\mathrm{H} 11$ & 1.36 & $-0.10 \pm 0.05$ & $1.71 \pm 0.55$ & 1.61 & 371 & 44 \\
\hline \multicolumn{7}{|c|}{ Laboratory incubations } \\
\hline $\mathrm{H} 1$ & 1.50 & $0.95 \pm 0.4$ & $4.11 \pm 0.99$ & 5.06 & - & 75 \\
\hline $\mathrm{H} 2$ & 1.92 & $0.81 \pm 0.34$ & $5.82 \pm 0.99$ & 6.63 & - & 75 \\
\hline $\mathrm{H} 3$ & 1.03 & $1.11 \pm 0.46$ & $4.74 \pm 0.87$ & 5.84 & - & 75 \\
\hline $\mathrm{H} 4$ & 0.65 & $0.39 \pm 0.16$ & $6.29 \pm 0.28$ & 6.68 & - & 75 \\
\hline $\mathrm{H} 19$ & 1.42 & $0.80 \pm 0.65$ & $8.36 \pm 1.37$ & 9.17 & - & 100 \\
\hline $\mathrm{H} 20$ & 1.52 & $0.82 \pm 0.05$ & $3.49 \pm 1.50$ & 4.31 & - & 100 \\
\hline
\end{tabular}

Note: Estimates of PAR in situ do not account for PAR attenuation through the incubation flasks and represent light conditions in the instrumented hole.

Table 4 shows sediment biogeochemical conditions associated with the 12 holes from which sediment samples were abstracted for estimation of bacterial production in the laboratory. Bacterial production (BP) was far lower (average $5.73 \pm 6.00 \mathrm{ng} C(\mathrm{~g} \text { cryoconite })^{-1} \mathrm{~d}^{-1}$ ) than community respiration rates shown in Table 3. Further, no statistically significant relationships (Pearson's correlation coefficient, significance level 5\%) between BP and the organic carbon content (average $1.48 \pm 0.41 \%$ ) were evident. The chlorophyll-a content of the debris showed considerable variability $\left(1.70 \pm 1.06 \mu \mathrm{g} \mathrm{chl} \mathrm{ag}^{-1}\right.$ ) (Table 3$)$.

The light curves produced for the six suspensions of cryoconite debris are described in Table 5. They show a significant range of maximum PP $(0.014-1.78 \mu \mathrm{g}$ C (g cryoconite $)^{-1} \mathrm{~h}^{-1}$ ) occurring at low light intensities (5.72$30.5 \mu \mathrm{mol} \mathrm{m} \mathrm{m}^{-2} \mathrm{~s}^{-1}$ ). The light curves therefore reveal adaptation to low light levels relative to the PAR measured at the surface of the ice at solar noon. The coefficient of determination also varies significantly, showing that at least one of the light curves was poorly defined (hole 5). In this case, photo-inhibition was not apparent but there was still a clear maximum rate of photosynthesis. Application of the light curves in Table 5 to the estimated in situ PAR levels in the instrumented cryoconite hole produced an average PP of $1.49 \mu \mathrm{gC}$ (g cryoconite $)^{-1} \mathrm{~d}^{-1}$. This compares favourably with the average PP values from the in situ incubations (Table 2) of $2.29 \mu \mathrm{gC}(\mathrm{g} \text { cryoconite })^{-1} \mathrm{~d}^{-1}$. Therefore our short-term incubations have probably captured realistic photosynthetic rates and confirm that the cryoconite communities are low-light-adapted.

\section{DISCUSSION}

The bacterial cell counts in the present study revealed far fewer cells $\left(1.7 \times 10^{6}\right.$ to $5.6 \times 10^{6}$ cells $\left.(\mathrm{g} \text { cryoconite })^{-1}\right)$ than in Arctic and alpine cryoconite sediments $\left(9.5 \times 10^{8}\right.$ to
$3.9 \times 10^{9}$ cells $\mathrm{g}^{-1}$ ). More cells were also found to be associated with cryoconite debris in the BIA of Patriot Hills, Antarctica $\left(9.2 \times 10^{7}\right.$ cells $\left.\mathrm{g}^{-1}\right)$ (all data from Anesio and others, 2010). The relatively low cell abundance also appears to be the case with the plankton community in the water $\left(0.95 \times 10^{2}\right.$ to $5.62 \times 10^{2}$ cells $\left.\mathrm{mL}^{-1}\right)$ when it is compared with a range of $1.3 \times 10^{4}$ to $10.6 \times 10^{4}$ cells mL $\mathrm{mL}^{-1}$ in all the environments reviewed by Anesio and others (2010). However, these numbers still show that, as in Anesio and others (2010), the bacterial biomass of Vestfold Hills cryoconite is largely associated with the sediment layer. For example, the lowest mass ratio of sediment to water in the cryoconite holes of the Cryoplot was 1:33 (data not shown), implying that $\sim 450$ times more bacteria were present in the

Table 4. Cryoconite debris characteristics, including the position relative to the ice surface, the chlorophyll-a content (Chl a), organic matter $(\mathrm{LOl})$, dissolved oxygen $\left(\mathrm{DO}_{2}\right)$ in the water and bacterial production (BP) inferred from the leucine incorporation

\begin{tabular}{lcccccc}
\hline ID & Position & Depth & $\mathrm{Chl} \mathrm{a}$ & $\mathrm{DO}_{2}$ & LOI & BP \\
& & $\mathrm{cm}$ & $\mu \mathrm{gg}^{-1}$ & $\mathrm{ppm}$ & $\%$ & $\mathrm{ng} \mathrm{Cg}^{-1} \mathrm{~d}^{-1}$ \\
& & & & & & \\
\hline $\mathrm{H} 1$ & Ridge & 80 & 0.49 & 14.4 & 1.56 & $2.89 \pm 0.23$ \\
$\mathrm{H} 2$ & Ridge & 86 & 0.66 & 15.9 & 1.58 & $5.14 \pm 0.73$ \\
$\mathrm{H} 3$ & Trough & 32 & 0.90 & 16.5 & 0.78 & $9.33 \pm 0.67$ \\
$\mathrm{H} 4$ & Trough & 35 & 1.64 & 16.5 & 0.83 & $23.5 \pm 2.3$ \\
$\mathrm{H} 11$ & Trough & 30 & 2.97 & 16.3 & 1.49 & $1.74 \pm 0.09$ \\
$\mathrm{H} 12$ & Trough & 32 & 1.18 & 18.1 & 1.33 & $5.90 \pm 0.22$ \\
$\mathrm{H} 13$ & Ridge & 82 & 3.33 & 14.7 & 1.30 & $3.23 \pm 0.33$ \\
$\mathrm{H} 14$ & Ridge & 83 & 3.61 & 14.4 & 1.99 & $4.12 \pm 0.30$ \\
$\mathrm{H} 15$ & Trough & 47 & 1.71 & 17.7 & 1.51 & $3.51 \pm 0.001$ \\
$\mathrm{H} 16$ & Ridge & 76 & 1.08 & 16.7 & 1.99 & $2.47 \pm 0.001$ \\
$\mathrm{H} 17$ & Ridge & 71 & 1.81 & 16.7 & n.d. & $2.60 \pm 0.001$ \\
$\mathrm{H} 18$ & Trough & 23 & 1.01 & 19.1 & 1.92 & $4.29 \pm 0.28$ \\
& & & & & & \\
\hline
\end{tabular}


Table 5. Characteristics of the six light curves established in the laboratory using ${ }^{14} \mathrm{C}-\mathrm{HCO}_{3}{ }^{-}$incorporation

\begin{tabular}{|c|c|c|c|c|c|c|c|}
\hline Sample & $\mathrm{P}^{\max } \mathrm{Chl} a$ & $\mathrm{P}^{\max }$ mass & Alpha & Beta & $\mathrm{C}$ & $E_{\mathrm{k}}$ & $r^{2}$ \\
\hline Hole 1 & 0.344 & 0.027 & 0.0141 & 0.00083 & 0.0104 & 30.5 & 0.97 \\
\hline Hole 2 & 0.071 & 0.031 & 0.0038 & 0.00031 & 0.0007 & 24.1 & 0.90 \\
\hline Hole 3 & 0.085 & 0.034 & 0.0047 & 0.00012 & -0.0003 & 20.3 & 0.96 \\
\hline Hole 4 & 0.045 & 0.021 & 0.0026 & 0.00006 & 0.0007 & 19.4 & 0.89 \\
\hline Hole 5 & 0.029 & 0.0064 & 0.0015 & 0.00006 & 0.0018 & 22.9 & 0.72 \\
\hline
\end{tabular}

$\mathrm{P}^{\mathrm{max}}$ is the maximum photosynthetic rate (shown normalized for both chlorophyll-a content and dry cryoconite debris mass $\left(\left(\mathrm{mg} C(\mathrm{mg} \text { chl a })^{-1} \mathrm{~h}^{-1}\right)\right.$ and $\left(\mu \mathrm{g} \mathrm{Cg}^{-1} \mathrm{~h}^{-1}\right)$ respectively); Alpha is the initial slope of the light-limited section of the curve $\left(\mathrm{mgC}\left(\mathrm{mg} \mathrm{chl} \mathrm{a}^{-1} \mathrm{~h}^{-1}\left(\mu \mathrm{mol} \mathrm{m} \mathrm{s}^{-1}\right)^{-1}\right)\right.$, Beta is the slope of photoinhibition $\left(\mathrm{mgC}\left(\mathrm{mg} \mathrm{chl} \mathrm{a}^{-1} \mathrm{~h}^{-1}\right)\left(\mu \mathrm{mol} \mathrm{m} \mathrm{m}^{-2} \mathrm{~s}^{-1}\right), \mathrm{C}\right.$ is the intercept $\left(\mathrm{mgC}(\mathrm{mg} \mathrm{chl} \mathrm{a})^{-1} \mathrm{~h}^{-1}\right)$, and $E_{\mathrm{k}}$ is the light intensity at which carbon uptake became saturated $\left(\mu \mathrm{mol} \mathrm{m} \mathrm{m}^{-2} \mathrm{~s}^{-1}\right.$.

sediment layer than in the total water column. However, average data from Table 2 suggest that the ratio would be just $1: 6$ in the case of microalgae, presumably because photosynthesis cannot occur beneath the surface of the sediment layer. The population of cells in the water layer is likely to be very sensitive to disturbance at the sedimentwater interface, so sampling, as well as natural processes of convection and gas ebullition (during melting and biological production), are likely to govern the microorganisms encountered in the pelagic environment. Much of our attention is therefore given to the sediment layer in the following discussion.

\section{Microbial community composition in the cryoconite holes}

Cameron and others (2012) used molecular methods to examine the microbial communities in nine Vestfold cryoconite holes sampled randomly from the Cryoplot as part of a comparative study involving Arctic and maritime Antarctic cryoconite. They used terminal restriction fragment length polymorphism (T-RFLP) to create signature 'fingerprints' of each community, facilitating a comparison of the abundance and diversity of dominant community members from hole to hole. Bacterial communities were found to be at least $50-60 \%$ similar to each other, with the exception of two communities, which had at least $30 \%$ or less similarity to other Vestfold bacterial community members. All of the dominant eukaryotic communities were found to be over $50 \%$ similar to each other. When further analysis of one of these communities (A-V4) was performed using 16S (bacterial) and 18S (eukaryotic) rRNA sequencing techniques, a diverse community was identified that was dominated by bacterial Betaproteobacteria, Gammaproteobacteria, Bacteriodetes and Cyanobacteria, and by eukaryotic Cercozoa, Alveolata and Tubulinea (Cameron and others, 2012). Of the autotrophic organisms in the A-V4 community, bacterial Cyanobacteria and eukaryotic Chloroplastida were most important, and they constituted $15 \%$ and $9 \%$ of the total abundance found in the analysis.

Many of the $16 \mathrm{~S}$ rRNA A-V4 clones were highly similar to GenBank clone submissions originating from a wide range of Antarctic or cryospheric ecosystems. These included soils (e.g. EF219607, Yergeau and others, 2007; FJ380174, Aislabie and others, 2009), glacial ice (e.g. AF479342, Christner, 2002), sea ice (e.g. AF468440, Brinkmeyer and others, 2003) and even penguin faeces (e.g. AY218729, Zhang and others, unpublished). There was no numerical sway towards one particular habitat being more represented in this analysis, suggesting that these communities may have been seeded from a mixture of surrounding ecosystems. Additionally, clones were often related to GenBank submissions isolated from terrestrial, freshwater and marine ecosystems that are not necessarily associated with the cryosphere (data not shown). In fact the majority of the $18 \mathrm{~S}$ rRNA clones were most closely related to GenBank clones associated with temperate soils (e.g. EF025015, Lesaulnier and others, 2008; AM114807, Moon-van der Staay and others, 2006).

\section{Light propagation to the autotrophs}

Wind polishing produces optical properties in the blue ice that allow the deep penetration of light and thus subsurface melting. The optical properties of the ice and the reflectance (albedo) of the debris beneath its surface therefore become the crucial factors that enable biological production within the ecosystem (with the additional benefit of providing protection from potentially harmful UV light). Although not measured in the present study, the albedo of cryoconite is reasonably well documented (see Hodson and others, 2008 and references therein) and typically lies between 0.10 and 0.4. However, the optical properties of blue ice are not well known, so PAR attenuation coefficients $(K)$ were calculated by statistically fitting the following model to the profiles in Figure 6:

$$
\operatorname{PAR}(Z)=\operatorname{PAR}_{0} \mathrm{e}^{-K Z}
$$

where $Z$ is the depth below the ice surface $(m)$ and $P A R_{0}$ is the PAR just beneath the surface. We used PAR profiles derived with an opaque cap over the hole, because it was apparent that up to $18 \%$ of the light in the upper $80 \mathrm{~cm}$ of the hole was being reflected down toward the sensor by the ice walls. Further, only the upper $60 \mathrm{~cm}$ of the profiles were used due to the nonlinearity of the log-transformed data at lower depths. This is a common problem owing to PAR readings being a spectral integral between 400 and $700 \mathrm{~m}$ and the fact that different wavelengths of light within this bandwidth are attenuated at different rates (hence the apparent blue colour of the ice). Table 6 shows the separate $K$ estimates for the snow-free ridge top and snow-covered (by $\sim 5 \mathrm{~cm}$ ) valley profiles, along with published values for snow, water, lake and sea ice. The ridge-top (snow-free) profiles indicated $K$ values of $\sim 2 \mathrm{~m}^{-1}$, while the trough profiles produced marginally greater values $\left(2.6 \mathrm{~m}^{-1}\right)$. Therefore, PAR propagation through glacier ice is far superior to dry snow (published range $14-20 \mathrm{~m}^{-1}$ ). The blue-ice values also lie within the range $\left(1-4 \mathrm{~m}^{-1}\right)$ described for 
Scandinavian lake ice covers by Lei and others (2011). However, the $K$ values reported in polar lakes are far lower, for example $0.034 \mathrm{~m}^{-1}$ beneath lake ice cover of the McMurdo Dry Valleys (Vincent and others, 1998).

Very low PAR attenuation coefficients can also be expected in the water layer above the cryoconite debris, because low levels of DOC were encountered here (Table 1) and no water colour was visible (in contrast to tea-coloured water described in certain holes by Tranter and others (2004)). This most likely reflects either the effective photolytic destruction of any coloured DOC evolving within the holes, or, more likely, the short duration of time since the holes were last flushed by new meltwater (in January). The new ice lids that were then observed on all the holes were notable in that they were level with the ice surface on the ridge tops, yet lower in the case of the trough holes (Fig. $1 \mathrm{~b}$ inset). The latter resembled half-filled pipes, with the upper part of the hole acting as an effective snow trap. Therefore, PAR penetration beneath these holes was probably far lower than our PAR profiles suggest, because the snow thickness was sometimes more than double that observed in the troughs where the boreholes were made. The shallower depths of cryoconite holes shown in the troughs (Fig. 5b) were therefore largely controlled by the effects of wind-blown snow accumulation and perhaps some shading by the valley sides.

In spite of the above complexity associated with PAR downwelling into Cryoplot, a key finding in this study is that the levels of irradiance reaching the cryoconite debris were broadly uniform, regardless of their depth (i.e. 9.0-11.5\% according to the midday boreholes and the continuous measurements shown in Fig. 2b). Such near-uniform light conditions suggest that cryoconite depths were at equilibrium with respect to the ablation rate at the ice surface (discussed below) and the solar heating of the debris within the hole. Several authors have described this equilibration process (e.g. Gribbon, 1979), and experiments on Arctic glaciers and Antarctic lake ice (Hodson and others, 2010a; Jepsen and others, 2010) show that the rates of debris melting into the ice surface allow it to reach its equilibrium depth within 1 or 2 days. This is sufficiently rapid to mean that short-term (e.g. diel) variations in solar radiation such as those shown in Figure $2 b$ will force the most important changes in the rate of photosynthesis upon the debris surface.

The observation that ice lids only lie flush with the ice surface upon the ridge holes suggests they were full of meltwater and began to refreeze before meltwater drainage was possible. By contrast, partial drainage of holes in the troughs prior to refreezing seems to have occurred. Two things might explain this: first, the hydraulic efficiency of the near-surface ice beneath the troughs might have been greater; and second, the thin snow cover in the troughs might have delayed refreezing there, allowing more time for partial drainage. We believe thermal-induced cracking is one reason why drainage might be more efficient in the troughs. Cracking was audible every day, resulting in a popping sound whose tone varied in accordance with the width, depth and water volume of the hole being cracked open. Since holes in the troughs were nearest to the ice surface, cracks were more likely to propagate to the water layer in the hole and initiate drainage. It is therefore possible that cracking enhances the ventilation and interconnectivity of the trough holes compared with their ridge-top counterparts. The ecological implications of these differences should therefore be explored in future.
Table 6. Attenuation coefficients $\left(\mathrm{m}^{-1}\right)$ for photosynthetically active radiation $\left(K_{\mathrm{PAR}}\right)$ in blue ice and various other cold aquatic environments

\begin{tabular}{lcc}
\hline Material & $K_{\text {PAR }}$ & Source \\
\hline Blue ice, no snow & 2.0 & This study \\
Blue ice with thin snow & 2.6 & $\begin{array}{c}\text { This study } \\
\text { Dry snow }\end{array}$ \\
$\begin{array}{lc}\text { Dry snow } \\
\text { Wet snow }\end{array}$ & $15-20$ & Lavoie and others (2005) \\
Lake ice & 7.5 & Lei and others (2011) \\
Lake ice & $1-4$ & Lei and others (2005) \\
$\begin{array}{l}\text { Lake water, Antarctic dry } \\
\text { valleys }\end{array}$ & 0.32 & Belzile and others (2001) \\
Lake water & 0.034 & Vincent and others (1998) \\
Sea ice & & \\
& 0.35 & Belzile and others (2001) \\
& 1.2 & Lavoie and others (2005)
\end{tabular}

\section{Biological production and nutrient balance in the Vestfold Hills cryoconite ecosystems}

Figure 8 shows average rates of NEP, PP and $R$ according to the in situ incubations conducted during the present study and also conducted by the authors using the same equipment in southwest Greenland and central Svalbard (Hodson and others, 2010a,b). The rates are clearly low in the Vestfold Hills cryoconite compared with the Arctic. Low rates of PP (0.4-1.4 $\mu \mathrm{g}$ C (g cryoconite) ${ }^{-1} \mathrm{~d}^{-1}$ ) have also been found with defrosted samples taken from Canada Glacier, McMurdo Dry Valleys, Antarctica, and incubated in the laboratory (Foreman and others, 2007). However, when the biological production measurements are normalized for total organic matter (rather than total debris mass), the rates of biological production in the various sites become rather similar (Fig. 8b). A shortage of organic debris supply might therefore limit biological production in the Vestfold Hills. In our study, the average chlorophyll-a specific rate of production (or assimilation number) was $0.06 \pm 0.02 \mu \mathrm{gC}(\mu \mathrm{g} \mathrm{chl} \mathrm{a})^{-1} \mathrm{~h}^{-1}$ for the in situ incubations and $0.32 \pm 0.13 \mu \mathrm{gC}(\mu \mathrm{g} \mathrm{chl} \mathrm{a})^{-1} \mathrm{~h}^{-1}$ for laboratory incubations. The rates are therefore typical of the lower values reported for Antarctic lakes by Henshaw and Laybourn-Parry (2002), and also the ultra-oligotrophic Crooked Lake in the vicinity of Flanders Moraine (Bayliss and others, 1997). As far as we are aware, these are the first estimates of the assimilation number for any cryoconite ecosystem. Photosynthetic efficiencies were low compared with polar lakes (i.e. $0.007 \pm 0.003$ and $0.004 \pm 0.001 \mu \mathrm{g} \mathrm{C}$ $(\mu \mathrm{g} \mathrm{chla})^{-1} \mathrm{~h}^{-1} \mu \mathrm{mol} \mathrm{m} \mathrm{m}^{-2} \mathrm{~s}^{-1}$ for the in situ and laboratory incubations respectively. Canadian high-Arctic lakes had photosynthetic efficiencies ranging between 0.53 and $2.30 \mathrm{~g}$ $\mathrm{C}(\mathrm{g} \mathrm{chl} \mathrm{a})^{-1} \mathrm{~h}^{-1} \mu \mathrm{mol} \mathrm{m} \mathrm{s}^{-1}$ (Markager and others, 1999), while in Antarctica the photosynthetic efficiencies ranged between 0.002 and $0.39 \mu \mathrm{g} \mathrm{C}(\mu \mathrm{g} \mathrm{chl} \mathrm{a})^{-1} \mathrm{~h}^{-1} \mu \mathrm{mol} \mathrm{m}{ }^{-2} \mathrm{~s}^{-1}$ at Beaver Lake (Laybourn-Parry and others, 2006) and between 0.02 and $5.19 \mu \mathrm{gC}(\mu \mathrm{g} \mathrm{chl} \mathrm{a})^{-1} \mathrm{~h}^{-1} \mu \mathrm{mol} \mathrm{m}^{-2} \mathrm{~s}^{-1}$ at Crooked Lake (Henshaw and Laybourn-Parry, 2002). One reason the estimates in Vestfold Hills cryoconite holes are low is that they are being compared with planktonic and not benthic systems, so shading effects are likely (see, e.g., Telling and others, 2012). A further reason is the entombment beneath the ice lid, which will limit the supply of TDIC and nutrients to periods of sporadic surface/near-surface runoff and melting at the hole floor during periods of surface ablation. Representative values for supply by the hole floor melting can be 

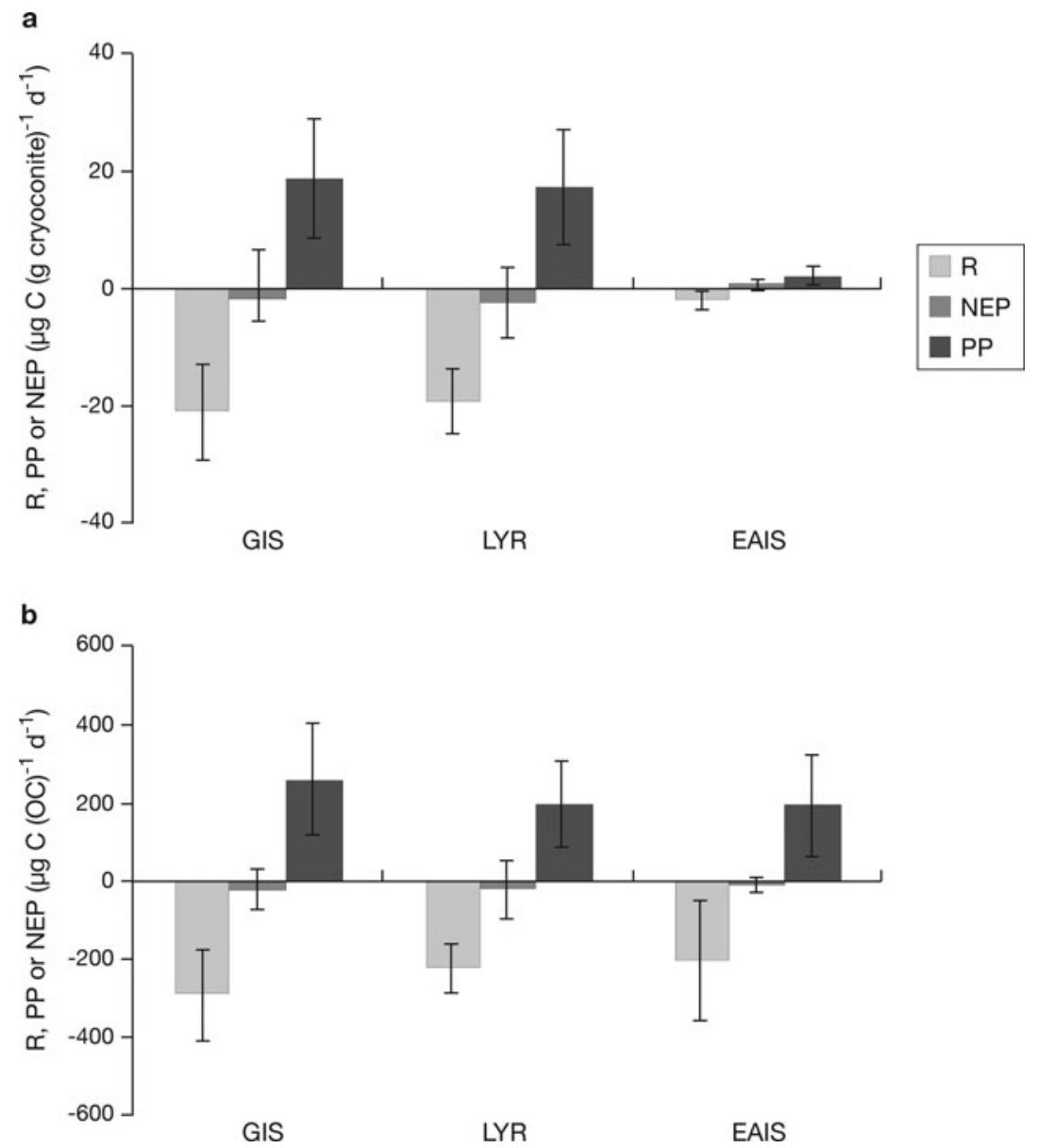

Fig. 8. Average rates of respiration $(R)$, net ecosystem production (NEP) and photosynthesis (PP) normalized for the total dry mass (a) and total mass of organic carbon (b). Data are shown for the present study (EAIS) and two other sites in the Arctic for comparison: Kangerlussuaq in Greenland (GIS), and Longyearbreen in Svalbard (LYR) (after Hodson and others 2010a,b respectively). Error bars are standard deviation of the multiple incubations conducted in each study.

calculated easily because melting at the base of the cryoconite hole appears to be in equilibrium with the surface ablation rate (the so-called 'equilibrium depth scenario'). A further assumption that the holes are hydrologically isolated is also necessary, which we think is reasonable on the ridges, where the hole depths appear to be safe from crack-induced drainage and were full prior to formation of the ice lid. This being the case, fluxes of nutrients into the holes approximate to the product of the daily surface ablation rate and the average nutrient content of glacier ice (Table 1). Average surface ablation was calculated to be $5.03 \mathrm{~mm} \mathrm{~d}^{-1}$ using ice surface measurements at the stake supporting the pyranometer in the Cryoplot. Table 7 shows the resulting nutrient flux calculations for dissolved inorganic $\mathrm{N}$ (i.e. $\mathrm{NH}_{4}{ }^{+}+\mathrm{NO}_{3}{ }^{-}$

Table 7. Renewal rates of DIN $\left(\mathrm{NO}_{3}{ }^{-}\right.$and $\left.\mathrm{NH}_{4}{ }^{+}\right)$and TDIC due to average melting conditions at the base of cryoconite holes

\begin{tabular}{llccc}
\hline & $\begin{array}{c}\text { Melt } \\
\text { renewal }\end{array}$ & $\begin{array}{c}\text { PP } \\
\text { (demand) }\end{array}$ & $\begin{array}{c}R \\
\text { (renewal) }\end{array}$ & $\begin{array}{c}\text { Net } \\
\text { demand }\end{array}$ \\
\hline $\operatorname{DIN~}\left(\mathrm{mg} \mathrm{N} \mathrm{m}^{-2} \mathrm{~d}^{-1}\right)$ & 0.035 & $-5.61^{*}$ & $3.33^{\dagger}$ & -2.3 \\
$\operatorname{TDIC}\left(\mathrm{mg} \mathrm{C} \mathrm{m}^{-2} \mathrm{~d}^{-1}\right)$ & 1.39 & -31.7 & 27.8 & -4.0 \\
\hline
\end{tabular}

*Estimated as $\mathrm{NH}_{4}{ }^{+}$assimilation using Redfield stoichiometry.

${ }^{\dagger}$ Measured $\mathrm{NH}_{4}^{+}$production in dark incubations. or 'DIN') and TDIC. Unfortunately, both $\mathrm{PO}_{4}{ }^{3-}$ and DOC in the glacier ice were below detection limits, so we limit our analyses here to just carbon and nitrogen. What is immediately clear is that the observed rates of PP and $R$ impose demands upon DIC and DIN resupply that cannot be met by ice melting at the base of the hole. For example, just $1.39 \mathrm{mg} \mathrm{C} \mathrm{m}^{-2} \mathrm{~d}^{-1}$ TDIC was typically liberated from ice melt, while $31.7 \mathrm{mg} \mathrm{C} \mathrm{m}^{-2} \mathrm{~d}^{-1}$ was fixed by primary production in the incubations. The implication therefore is that respired carbon is crucial for photosynthesis during entombment. Note that the glacier melt resupply rate, while low, is of the same order of magnitude as NEP (average $4.0 \mathrm{mg} \mathrm{C} \mathrm{m}^{-2} \mathrm{~d}^{-1}$ ). Tight coupling between the heterotrophic and autotrophic communities can therefore be expected on account of this TDIC limitation. The same can be deduced when the nitrogen balance is considered, because $\mathrm{NH}_{4}{ }^{+}$production was a clear feature of the dark incubations, yet it was not observed in the light incubations. This suggests that $\mathrm{NH}_{4}{ }^{+}$was being effectively recycled by primary production during photosynthesis. Table 7 suggests that a likely demand of DIN imposed by the observed PP (according to Redfield stoichiometry) was $5.61 \mathrm{mg} \mathrm{N} \mathrm{m}^{-2} \mathrm{~d}^{-1}$, which is almost satisfied by the observed liberation of $\mathrm{NH}_{4}^{+}$in the dark incubations (3.33 $\mathrm{mg} \mathrm{N} \mathrm{m}^{-2} \mathrm{~d}^{-1}$ ). Therefore, like the entombed holes of McMurdo Dry Valleys glaciers (Tranter and others, 2004), recycling of organic nutrients seems likely to meet the demands imposed by biological production. 
Another feature of the respiration measurements is that the average rates of bacterial production according to Table 4 were $\sim 300$ times lower (average $5.73 \mathrm{ng} \mathrm{Cg}^{-1} \mathrm{~d}^{-1}$ ) than average community respiration $\left(1870 \mathrm{ng} \mathrm{Cg}^{-1} \mathrm{~d}^{-1}\right.$; Table 3), and also lower than most rates deduced on Northern Hemisphere glaciers using an identical methodology to the present study (3.1-950 ng C (g cryoconite) ${ }^{-1} \mathrm{~d}^{-1}$; Anesio and others, 2010). It is therefore difficult to argue that bacteria are a significant source of the respired carbon, even if the bacterial growth efficiency is low. For example, just $30 \%$ of the average community respiration in Table 3 could be explained by average rates of bacterial production if their growth efficiency was only $1 \%$. Inorganic carbon production by carbonate weathering has already been accounted for in the carbon budget, and organic carbon photolysis cannot influence the dark respiration values. Therefore, unless experimental artefacts greatly influence the comparison of our ex situ bacterial production measurements and our in situ community respiration measurements, respiration by the autotrophic community and/or other heterotrophic organisms must be invoked. Cameron and others' (2012) study of the 16S rRNA gene clone libraries revealed several protists and other potential heterotrophs that could have been responsible for the unexplained community respiration. However, their abundance and activity were not established, so it remains unclear where the respired carbon originated.

\section{CONCLUSIONS}

Strong feedbacks between physical and biological processes are responsible for the establishment of ecosystems within BIAs and their protection from two major stresses: water shortage at sub-freezing temperatures and harmful irradiance during daylight. Collectively, these BIA ecosystems represent major oases for microbial life and extend the range of photosynthesis occurring upon the Earth's surface to include the margins of its coldest ice sheet. However, the cost of this shady refuge is that only modest rates of photosynthesis are achieved, owing to the low-light conditions and the entombment of the ecosystem beneath ice lids. For this reason, the BIA ecosystems of Antarctica show low rates of biological production relative to the Arctic because low light levels and strong limitations upon TDIC and nutrient supply are imposed. However, the fact that biological production is detectable clearly shows that the ice sheet is advecting labile nutrients and viable microorganisms towards its margins. Whether these are recently colonizing microorganisms that are supplied by winds from other ecosystems beyond the ice margin, or ancient cells that are melted out of the ice is unclear. The role of ancient microbial cells advected into the BIA by glacier flow therefore remains elusive and requires research attention now that biological production within these habitats has been established.

\section{ACKNOWLEDGEMENTS}

We thank the University of Tasmania and the Australian Antarctic Research Assessment Committee (grant 2750) for funding to Laybourn-Parry, and the Leverhulme Trust (RF/4/ RFG/2007/0398) and the UK Natural Environment Research Council (NE/H01446/1) for funding to Hodson. Joseph Taunton, Ryan Ruddick and Alex Woods helped with the micro-topographic survey data, while Mike Grimmer and others at Davis Base helped in the field. We are also grateful to Kath Taylor who conducted the nutrient analyses, Paul Thomson who conducted the flow cytometry and Andrew Davidson who used resources from his own project to support our study at Davis.

\section{REFERENCES}

Adams N (2008) The role of the polar jet in modulating the surface weather around coastal Antarctica - a case study. In Third Antarctic Meteorological Observation, Modeling, and Forecasting Workshop, 9-12 June 2008, Madison, WI, USA. http:// amrc.ssec.wisc.edu/meetings/meeting2008/presentations/Day3/ NAdams_AMOMFW_2008.pdf.

Aislabie J, Jordan S, Ayton J, Klassen JL, Barker GM and Turner S (2009) Bacterial diversity associated with ornithogenic soil of the Ross Sea region, Antarctica. Can. J. Microbiol., 55(1), 21-36 (doi: 10.1139/W08-126)

Anesio AM and Laybourn-Parry J (2012) Glaciers and ice sheets as a biome. Trends Ecol. Evol., 27(4), 219-225 (doi: 10.1016/j.tree. 2011.09.012)

Anesio AM and 6 others (2010) Carbon fluxes through bacterial communities on glacier surfaces. Ann. Glaciol., 51(56), 32-40 (doi: 10.3189/172756411795932092)

Bayliss P, Ellis-Evans JC and Laybourn-Parry J (1997) Temporal patterns of primary production in a large ultra-oligotrophic Antarctic freshwater lake. Polar Biol., 18(6), 363-370 (doi: 10.1007/s003000050201)

Belzile C, Vincent WF, Gibson JAE and Van Hove P (2001) Biooptical characteristics of the snow, ice, and water column of a perennially ice-covered lake in the High Arctic. Can. J. Fish. Aquat. Sci., 58(12), 2405-2418 (doi: 10.1139/cjfas-58-12-2405)

Brandt O, Taurisano A, Giannopoulos A and Kohler J (2009) What can GPR tell us about cryoconite holes? 3D FDTD modeling, excavation and field GPR data. Cold Reg. Sci. Technol., 55(1), 111-119 (doi: 10.1016/j.coldregions.2008.06.002)

Brinkmeyer R, Knittel K, Jürgens J, Weyland $H$, Amann $R$ and Helmke E (2003) Diversity and structure of bacterial communities in Arctic versus Antarctic pack ice. Appl. Environ. Microbiol., 69(11), 6610-6619 (doi: 10.1128/AEM.69.11. 6610-6619.2003)

Cameron KA, Hodson AJ and Osborn AM (2012) Structure and diversity of bacterial, eukaryotic and archaeal communities in glacial cryoconite holes from the Arctic and the Antarctic. FEMS Microbiol. Ecol., 82(2), 254-267 (doi: 10.1111/j.1574-6941. 2011.01277.x)

Carpenter EJ, Lin S and Capone DG (2000) Bacterial activity in South Pole snow. Appl. Environ. Microbiol., 66(10), 4514-4517 (doi: 10.1128/AEM.66.10.4514-4517.2000)

Christner BC (2002) Recovery of bacteria from glacial and subglacial environments. (PhD thesis, Ohio State University)

Christner BC, Kvito BH and Reeve JN (2003) Molecular identification of bacteria and eukarya inhabiting an Antarctic cryoconite hole. Extremophiles, 7(3), 177-183 (doi: 10.1007/s00792-002-0309-0)

Drever JI (1997) The geochemistry of natural waters: surface and groundwater environments. Prentice-Hall, Englewood Cliffs, NJ

Foreman CM, Sattler B, Mikucki DL, Porazinska DL and Priscu JC (2007) Metabolic activity and diversity of cryoconites in the Taylor Valley, Antarctica. J. Geophys. Res., 112(G4), G04S32 (doi: 10.1029/2006JG000358)

Fountain AG, Nylen TH, Tranter M and Bagshaw E (2008) Temporal variations in physical and chemical features of cryoconite holes on Canada Glacier, McMurdo Dry Valleys, Antarctica. J. Geophys. Res., 113(G1), G01S92 (doi: 10.1029/ 2007JG000430)

Gribbon PWF (1979) Cryoconite holes on Sermikavsak, West Greenland. J. Glaciol., 22(86), 177-181

Henshaw T and Laybourn-Parry J (2002) The annual patterns of photosynthesis in two large, freshwater, ultra-oligotrophic 
Antarctic lakes. Polar Biol., 25(10), 744-752 (doi: 10.1007/ s00300-002-0402-y)

Hodson A and 7 others (2008) Glacial ecosystems. Ecol. Monogr., 78(1), 41-67 (doi: 10.1890/07-0187.1)

Hodson AJ and 6 others (2010a) The cryoconite ecosystem on the Greenland ice sheet. Ann. Glaciol., 51(56), 123-129 (doi: 10.3189/172756411795931985)

Hodson AJ and 6 others (2010b) The structure, biological activity and biogeochemistry of cryoconite aggregates upon an Arctic valley glacier: Longyearbreen, Svalbard. J. Glaciol., 56(196), 349-362 (doi: 10.3189/002214310791968403)

Jepsen SM, Adams EE and Priscu JC (2010) Sediment melt-migration dynamics in perennial Antarctic lake ice. Arct. Antarct. Alp. Res., 42(1), 57-66

Kirchman D (2001) Measuring bacterial biomass production and growth rates from leucine incorporation in natural aquatic environment. In Paul JH ed. Marine microbiology. (Methods in Microbiology 30) Academic Press, London, 227-237

Langford H, Hodson A, Banwart S and Bøggild C (2010) The microstructure and biogeochemistry of Arctic cryoconite granules. Ann. Glaciol., 51(56), 87-94 (doi: 10.3189/ 172756411795932083)

Lavoie D, Denman K and Michel C (2005) Modeling ice algal growth and decline in a seasonally ice-covered region of the Arctic (Resolute Passage, Canadian Archipelago). J. Geophys. Res., 110(C11), C11009 (doi: 10.1029/2005JC002922)

Laybourn-Parry J, Madan NJ, Marshall WA, Marchant H and Wright SW (2006) Carbon dynamics in an ultra-oligotrophic epishelf lake (Beaver Lake, Antarctica) in summer. Freshwater Biol., 51(6), 1116-1130 (doi: 10.1111/j.1365-2427.2006.01560.x)

Lei R, Leppäranta $M$, Erm A, Jaatinen E and Pärn O (2011) Field investigations of apparent optical properties of ice cover in Finnish and Estonian lakes in winter 2009. Estonian J. Earth Sci., 60(1), 50-64 (doi: 10.3176/earth.2011.1.05)

Lesaulnier $\mathrm{C}$ and 7 others (2008) Elevated atmospheric $\mathrm{CO}_{2}$ affects soil microbial diversity associated with trembling aspen. Environ. Microbiol., 10(4), 926-941 (doi: 10.1111/j.1462-2920. 2007.01512.x)

Liston GE and Winther J-G (2005) Antarctic surface and subsurface snow and ice melt fluxes. J. Climate, 18(10), 1469-1481 (doi: 10.1175/JCLI3344.1)

Markager S, Vincent WF and Tang EPY (1999) Carbon fixation by phytoplankton in high Arctic lakes: implications of low temperature for photosynthesis. Limnol. Oceanogr., 44(3), 597-607 (doi: 10.4319/lo.1999.44.3.0597)

Marshall WA (1996) Biological particles over Antarctica. Nature, 383(6602), 680 (doi: 10.1038/383680a0)

Moon-van der Staay SY, Tzeneva VA, Van der Staay G, de Vos WM, Smidt $\mathrm{H}$ and Hackstein JHP (2006) Eukaryotic diversity in historical soil samples. FEMS Microbiol. Ecol., 57(3), 420-428 (doi: 10.1111/j.1574-6941.2006.00130.x)

Mueller DR and Pollard WH (2004) Gradient analysis of cryoconite ecosystems from two polar glaciers. Polar Biol., 27(2), 66-74 (doi: 10.1007/s00300-003-0580-2)

Pearce DA, Bridge PD, Hughes KA, Sattler B, Psenner R and Russell NJ (2009) Microorganisms in the atmosphere over Antarctica. FEMS Microbiol. Ecol., 69(2), 143-157 (doi: 10.1111/j.15746941.2009.00706.x)
Platt T, Gallegos CL and Harrison WG (1980) Photoinhibition of photosynthesis in natural assemblages of marine phytoplankton. J. Mar. Res., 38(4), 687-701

Price PB (2007) Microbial life in glacial ice and implications for a cold origin of life. FEMS Microbiol. Ecol., 59(2), 217-231 (doi: 10.1111/j.1574-6941.2006.00234)

Priscu JC, Tulaczyk S, Studinger M, Kennicutt MCl, Christner BC and Foreman CM (2008) Antarctic subglacial water: origin, evolution and ecology. In Vincent W and Laybourn-Parry J eds. Polar lakes and rivers: limnology of Arctic and Antarctic aquatic ecosystems. Oxford University Press, Oxford, 119-135

Sinisalo A and Moore JC (2010) Antarctic blue-ice areas - towards extracting palaeoclimate information. Antarct. Sci., 22(2), 99-115 (doi: 10.1017/S0954102009990691)

Smith DC and Azam F (1992) A simple, economical method for measuring bacterial protein synthesis rates in seawater using $3 \mathrm{H}$ leucine. Mar. Microb. Food Webs, 6(2), 107-114

Stibal M, Telling J, Cook J, Mak KM, Hodson A and Anesio AM (2011) Environmental controls on microbial abundance and activity on the Greenland ice sheet: a multivariate analysis approach. Microbial Ecol., 63(1), 74-84 (doi: 10.1007/s00248011-9935-3)

Talling JF (1969) General outline of spectrophotometric methods. In Vollenweider RA, Talling JF and Westlake DF, eds. A manual on methods for measuring primary production in aquatic environments. (International Biological Programme Handbook 12) Blackwell Scientific, Oxford

Telling J and 9 others (2012) Controls on the autochthonous production and respiration of organic matter in cryoconite holes on high Arctic glaciers. J. Geophys. Res., 117(G1), G01017 (doi: 10.1029/2011JG001828)

Tranter M and 6 others (2004) Extreme hydrochemical conditions in natural microcosms entombed within Antarctic ice. Hydrol. Process., 18(2), 379-387 (doi: 10.1002/hyp.5217)

Vincent WF (1988) Microbial ecosystems of Antarctica. Cambridge University Press, Cambridge

Vincent WF, Rae R, Laurion I, Howard-Williams C and Priscu JC (1998) Transparency of Antarctic ice-covered lakes to solar UV radiation. Limnol. Oceanogr., 43(4), 619-624

Westwood KJ, Griffiths FB, Meiners KM and Williams GD (2010) Primary productivity off the Antarctic coast from $30^{\circ}-80^{\circ} \mathrm{E}$; BROKE-West survey, 2006. Deep-Sea Res. II, 57(9-10), 794-814 (doi: 10.1016/j.dsr2.2008.08.020)

Wharton RA, Jr, Vinyard WC, Parker BC, Simmons GM, Jr and Seaburg KG (1981) Algae in cryoconite holes on Canada Glacier in southern Victoria Land, Antarctica. Phycologia, 20(2), 208-211 (doi: 10.2216/i0031-8884-20-2-208.1)

Winther J-G, Jespersen MN and Liston GE (2001) Blue-ice areas in Antarctica derived from NOAA AVHRR satellite data. J. Glaciol., 47(157), 325-334 (doi: 10.3189/172756501781832386)

Yergeau E, Newsham KK, Pearce DA and Kowalchuk GA (2007) Patterns of bacterial diversity across a range of Antarctic terrestrial habitats. Environ. Microbiol., 9(11), 2670-2682 (doi: 10.1111/j.1462-2920.2007.01379.x)

Zhang R, Zeng R, Zhao J and Lin N (unpublished) Diversity of bacteria in penguin droppings sediments from Ardley Island, Antarctica. http://ftp.dna.affrc.go.jp/pub/dna_all/A/Y1/88/32/ AY188326/AY188326 